Article

\title{
Plasma Catalysis: Distinguishing between Thermal and Chemical Effects
}

\author{
Guido Giammaria ${ }^{1}$, Gerard van Rooij ${ }^{2}$ and Leon Lefferts ${ }^{1, *(D)}$ \\ 1 Catalytic Processes and Materials Group, University of Twente, 7522 NB Enschede, The Netherlands; \\ g.giammaria@utwente.nl \\ 2 Nonequilibrium Fuel Conversion, DIFFER, 5612 AJ Eindhoven, The Netherlands; G.J.vanRooij@differ.nl \\ * Correspondence: 1.lefferts@utwente.nl; Tel.: +31-53-489-2922
}

Received: 21 January 2019; Accepted: 7 February 2019; Published: 16 February 2019

check for updates

\begin{abstract}
The goal of this study is to develop a method to distinguish between plasma chemistry and thermal effects in a Dielectric Barrier Discharge nonequilibrium plasma containing a packed bed of porous particles. Decomposition of $\mathrm{CaCO}_{3}$ in Ar plasma is used as a model reaction and $\mathrm{CaCO}_{3}$ samples were prepared with different external surface area, via the particle size, as well as with different internal surface area, via pore morphology. Also, the effect of the $\mathrm{CO}_{2}$ in gas phase on the formation of products during plasma enhanced decomposition is measured. The internal surface area is not exposed to plasma and relates to thermal effect only, whereas both plasma and thermal effects occur at the external surface area. Decomposition rates were in our case found to be influenced by internal surface changes only and thermal decomposition is concluded to dominate. This is further supported by the slow response in the $\mathrm{CO}_{2}$ concentration at a timescale of typically 1 minute upon changes in discharge power. The thermal effect is estimated based on the kinetics of the $\mathrm{CaCO}_{3}$ decomposition, resulting in a temperature increase within $80{ }^{\circ} \mathrm{C}$ for plasma power from 0 to $6 \mathrm{~W}$. In contrast, $\mathrm{CO}_{2}$ dissociation to $\mathrm{CO}$ and $\mathrm{O}_{2}$ is controlled by plasma chemistry as this reaction is thermodynamically impossible without plasma, in agreement with fast response within a few seconds of the $\mathrm{CO}$ concentration when changing plasma power. $\mathrm{CO}$ forms exclusively via consecutive dissociation of $\mathrm{CO}_{2}$ in the gas phase and not directly from $\mathrm{CaCO}_{3}$. In ongoing work, this methodology is used to distinguish between thermal effects and plasma-chemical effects in more reactive plasma, containing, e.g., $\mathrm{H}_{2}$.
\end{abstract}

Keywords: nonequilibrium plasma; plasma catalysis; gas temperature; calcium carbonate decomposition

\section{Introduction}

Plasma catalysis is receiving more and more attention in the last few years, since the specific interactions between plasma and catalyst surface may lead to synergistic effects [1-4]. One of the earliest plasma catalytic applications is the abatement of volatile organic compounds (VOC) [5,6], while in the last decade research has been focused more on $\mathrm{CO}_{2}$ conversion [7-9], conversion of hydrocarbons via reforming, and coupling [10-12], as well as activation of $\mathrm{N}_{2}$ [13,14]. Reforming of hydrocarbons is an example of an endothermic reaction, where plasma catalysis holds promise because of activation of hydrocarbons at low temperature, but also because electrical energy would be used to generate the required heat. Methane coupling and $\mathrm{CO}_{2}$ dissociation are examples of thermodynamically hill-up reactions, which are clearly more challenging.

Nonequilibrium plasma, e.g., microwave of Dielectric Barrier Discharge (DBD) plasma, is especially attractive because it operates at relatively low temperatures [15-17]. Consequently, catalyst sintering is prevented. Moreover, low temperatures are a necessity to enable catalysis in the first place, 
facilitating initial adsorption that decreases entropy. Starting and stopping plasma reactors is much faster than usual thermal reactors, which is an advantage when fast capacity changes are required, e.g., in connection with intermittent energy supply and storage.

DBD plasma is frequently used for studying plasma catalytic conversion. The high AC voltages applied at relatively low frequency $\left(50\right.$ to $10^{5} \mathrm{~Hz}$ ) produces a nonequilibrium plasma with very high electron temperatures $\left(1-10 \mathrm{eV}\right.$ equal to $\left.10^{4}-10^{5} \mathrm{~K}\right)$, rather high vibrational temperatures $\left(10^{3} \mathrm{~K}\right)$, and rather low rotational and translational temperatures in the plasma zone, typically in the order or smaller than $100 \mathrm{~K}$ [6,15-17]. The fact that energy would be directed directly to bond breaking, without the need to heat up the gas mixture completely, is very attractive as heat exchangers to recover the heat would become redundant. The presence of a dielectric between the two electrodes prevents the formation of hot plasma in a single spark, forming instead several microfilaments, resulting in a more uniform plasma. The low gas temperature allows the application of a catalyst directly in the plasma generation zone without fast deactivation, maximizing the interaction between active species and the catalytic phase. Furthermore, DBD plasma can be generated at atmospheric pressure, which is interesting from the application point of view. Very promising results were presented in the last years on several topics, such as $\mathrm{CO}_{2}$ conversion [9,18-27] and $\mathrm{CH}_{4}$ reforming [12,13,28-34], in terms of high conversion and selectivity. However, the main issue of DBD remains the low energy efficiency achieved, i.e., the ratio between chemical energy stored in the produced molecules and electrical energy applied, which rarely surpasses $10 \%$. This is explained by dissociative excitation by electron impact, involving a large activation barrier, dominating over vibrational excitation [7,35-37]. A more suitable technique for vibrational excitation is microwave plasma, which uses $\mathrm{GHz}$ frequencies [38-40]. However, the temperature increase is more pronounced in microwave plasma, limiting the opportunities for plasma catalysis.

Interaction between plasma and catalyst can proceed in many ways [1-4]. Obviously, the plasma will introduce new chemical species including activated species, radicals, and ions, which may all adsorb on the catalyst opening new reaction pathways and influencing the products distribution. Plasma can also induce photocatalytic effects by UV irradiation, impingement of charged particles and thermal fluctuations. The surface and subsurface of a catalyst can be modified by plasma via poisoning, implantation, sputtering, and etching. The presence of a catalyst influences the plasma by changing the electrical field distribution, but also modifying the free volume and the residence time in the plasma zone. Plasma also affects the temperature of the system, obviously influencing reaction rates of chemical reactions.

Unfortunately, it is not possible to measure the temperature in a DBD plasma catalytic reactor directly. Application of a thermocouple inside the plasma is not possible due to the high electric fields present. Nevertheless, thermocouples were used a few millimeters outside the plasma zone inside the reactor tube, or outside the reactor tube just alongside the plasma zone [41-44]. Furthermore, many attempts have been done to measure temperatures indirectly, for instance by emission spectroscopy of UV-Vis radiation probing electronic transitions in nitrogen and hydroxyl groups [45-48], by UV absorption spectroscopy [47], or by infrared emission [23,44]. Unfortunately, these methods have serious limitation depending on the reactor material properties as well as the packed bed properties.

This study proposes a method to distinguish between thermal effect and plasma chemistry effects in fixed bed DBD plasma reactors. The decomposition of calcium carbonate is used as a model system for packed beds containing porous particles. It is well known that thermal decomposition results in formation of exclusively $\mathrm{CaO}$ and $\mathrm{CO}_{2}$ [49], whereas formation of $\mathrm{CO}$ would indicate that plasma chemistry is involved. A pure thermal effect is likely when using an Ar plasma, since no chemistry is expected between activated argon species and $\mathrm{CaCO}_{3}$. The choice for $\mathrm{CaCO}_{3}$ as model system in combination with a DBD reactor is inspired by its relevance for $\mathrm{CO}_{2}$ separation. The calcium looping cycle consists of carbonation of $\mathrm{CaO}$ for capturing followed by calcination of $\mathrm{CaCO}_{3}$ in order to recycle calcium oxide and to produce pure $\mathrm{CO}_{2}$ [49]. Bottleneck is the calcination reaction that requires high temperatures in order to achieve high $\mathrm{CO}_{2}$ concentrations in the outlet, i.e., at least $950{ }^{\circ} \mathrm{C}$ to achieve 
1 bar $\mathrm{CO}_{2}$ [50]. Such temperatures result in sintering, decreasing the $\mathrm{CO}_{2}$ capture capacity when calcium oxide is recycled multiple times [51-53]. Using a DBD plasma during the calcium carbonate decomposition might circumvent the need for such high temperatures, and in addition $\mathrm{CO}_{2}$ will be converted by plasma into $\mathrm{CO}$, converting electrical energy into chemical energy and producing an added-value product.

The method to distinguish between thermal and plasma chemistry is based on the fact that plasma cannot exist in the pores inside particles if they are smaller than a few micrometers, as can be understood from Paschen's Law, which is generally accepted [54,55]. It was recently reported in a theoretical study that penetration of plasma in pores is possible to some extent [56]; however, we will discuss that under our conditions the plasma is limited to the interparticle volume and the external surface area is exposed under the conditions applied. The internal surface area, caused by the presence of small pores in the material is not exposed to the plasma, but would be influenced by any thermal effect. The theory is explained in detail in the section Methods in Appendix B and shown in Figure A13. The method then consists of two approaches: first, the effects of both the internal surface area as well as external surface area will be explored, and second, the dynamics of the performance on changing plasma power will be evaluated. Decomposition rate and eventual further reactions of the carbon dioxide product will be assessed. Argon plasma is used as a reference for the method to be developed as to distinguish between thermal effects and plasma-chemical effects.

\section{Results}

X-ray fluorescence (XRF) measurements confirmed the purity of $\mathrm{CaO}(99.12 \%)$ containing some minor impurities, i.e., $\mathrm{SiO}_{2}(0.16 \%), \mathrm{MgO}(0.12 \%)$, and $\mathrm{Al}_{2} \mathrm{O}_{3}(0.095 \%)$.

Table 1 in the Materials and Methods Section presents the surface area and particles sizes of the five prepared samples. The surface areas reported for samples A and B are well reproducible, but it should be noted that systematic errors may be larger, given the relatively low value of the surface areas. The surface area of batch III (samples C-E) is below the detection limit of the $\mathrm{N}_{2}$ physisorption equipment, from which we deduce that the surface area is below $0.5 \mathrm{~m}^{2} / \mathrm{g}$. In any case, the total surface of the samples increases in the order $\mathrm{C}<\mathrm{B}<\mathrm{A}$. Remarkably, the surface areas of the parent oxides are much higher, confirming the theory that formation of a carbonate layer induces closure of small pores, due to the lower density of $\mathrm{CaCO}_{3}\left(2.71 \mathrm{~g} \mathrm{~cm}^{-3}\right)$ compared to $\mathrm{CaO}\left(3.35 \mathrm{~g} \mathrm{~cm}^{-3}\right)$. However, the order in surface area remains the same, reassuring that the surface area of the samples is in the order $\mathrm{A}>\mathrm{B}>\mathrm{C}>\mathrm{D}>\mathrm{E}$. Figure 1 shows the pore size distribution measured with mercury porosimetry for the carbonated samples synthesized from calcium ascorbate (sample B, Figure 2a) and from calcium carbonate (sample C, Figure $2 \mathrm{~b}$ ). Sintering at $900{ }^{\circ} \mathrm{C}$ for $24 \mathrm{~h}$ (sample C) causes formation of large pores of typically $400 \mathrm{~nm}$, compared to sample A which was treated with $\mathrm{CO}_{2}$ only at $630{ }^{\circ} \mathrm{C}$. Remarkably, the pore volume of the sintered sample is $\sim 20 \%$, much larger than sample B $(\sim 5 \%)$, indicating that smaller pores collapsed favoring enlargement of the bigger pores.

Table 1. Characteristics of the samples prepared from three different precursors.

\begin{tabular}{|c|c|c|c|c|c|c|}
\hline $\begin{array}{l}\text { Sample } \\
\text { Code }\end{array}$ & $\begin{array}{l}\text { Precursor } \\
\text { (Batch \#) }\end{array}$ & $\begin{array}{c}\text { Carbonation } \\
\text { Time at } \\
630^{\circ} \mathrm{C}(\mathrm{h})\end{array}$ & $\begin{array}{c}\text { Sintering } \\
\text { Time at } \\
900^{\circ} \mathrm{C}(\mathrm{h})\end{array}$ & $\begin{array}{l}\text { CaO S.S.A. } \\
\left(\mathrm{m}^{2} \mathrm{~g}^{-1}\right)\end{array}$ & $\begin{array}{c}\mathrm{CaCO}_{3} \\
\text { S.S.A. } \\
\left(\mathrm{m}^{2} \mathrm{~g}^{-1}\right) \\
\end{array}$ & $\begin{array}{c}\text { Particles } \\
\text { Diameter } \\
(\mu \mathrm{m})\end{array}$ \\
\hline A & Ca Gluconate (I) & 5 & 0 & 46.2 & $1.7 \pm 0.1$ & $250-300$ \\
\hline B & Ca Ascorbate (II) & 4 & 0 & 23.2 & $0.8 \pm 0.1$ & $250-300$ \\
\hline $\mathrm{C}$ & $\mathrm{CaCO}_{3}(\mathrm{III})$ & 5 & 24 & 10.1 & $<0.5$ & $250-300$ \\
\hline $\mathrm{D}$ & $\mathrm{CaCO}_{3}$ (III) & 5 & 24 & 10.1 & $<0.5$ & $100-125$ \\
\hline $\mathrm{E}$ & $\mathrm{CaCO}_{3}$ (III) & 5 & 24 & 10.1 & $<0.5$ & $38-45$ \\
\hline
\end{tabular}




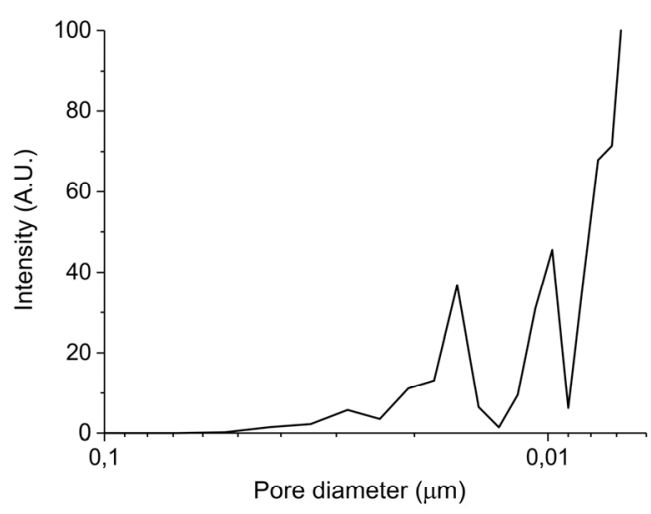

(a)

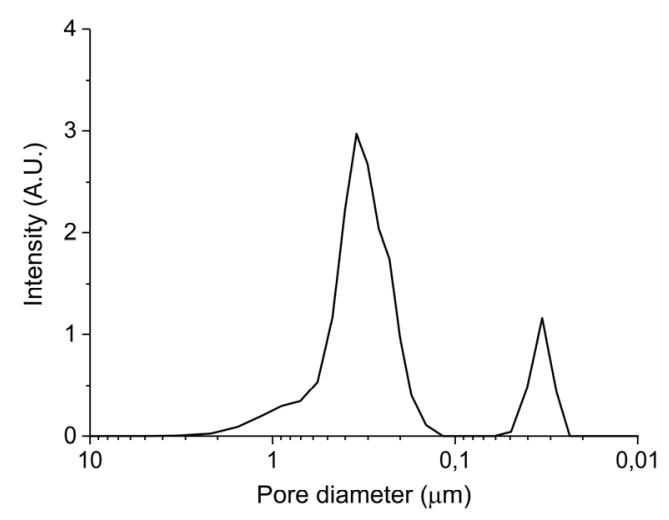

(b)

Figure 1. (a) Pore size distribution for sample B batch II and (b) pore size distribution for sample C batch III according $\mathrm{Hg}$ porosimetry.

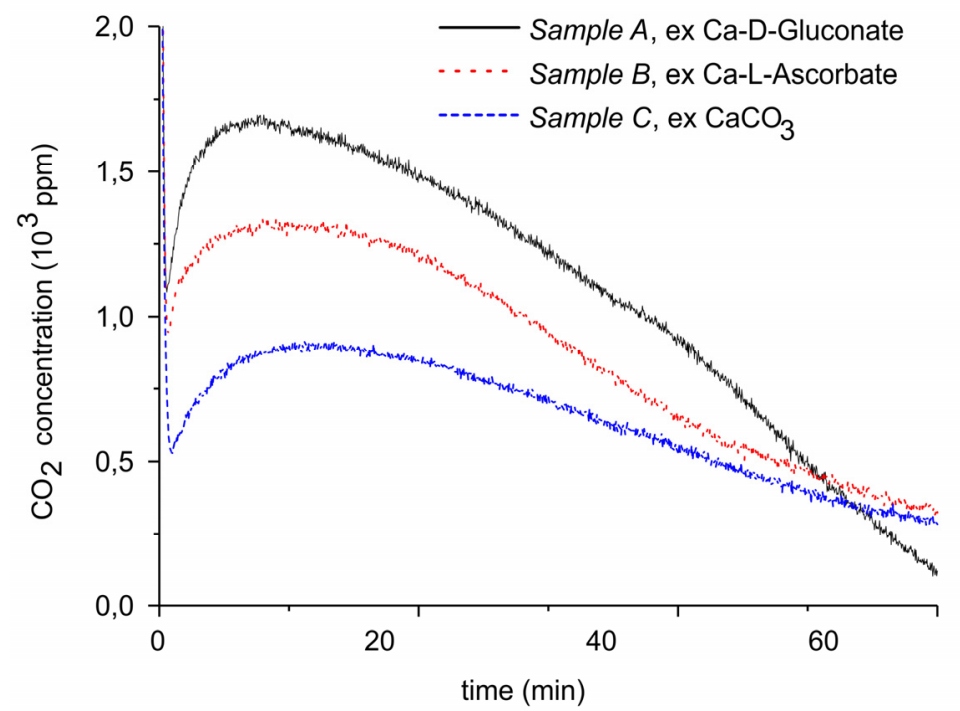

Figure 2. $\mathrm{CO}_{2}$ concentration monitored by mass spectrometry during decomposition of carbonated sample A (solid line), sample B (dotted line), and sample C (dashed line). The temperature is $630{ }^{\circ} \mathrm{C}$, flow rate is $30 \mathrm{~mL} \mathrm{~min}^{-1}$, and the gas is pure Ar.

Figure 2 presents the results of isothermal decomposition at $630{ }^{\circ} \mathrm{C}$ of the carbonated samples A-C, showing that the $\mathrm{CO}_{2}$ concentration generated via decomposition is within $10 \%$ constant during typically $20 \mathrm{~min}$, after an induction time of a few minutes. In general, this is observed when decomposition is limited to $\max 50 \%$ of $\mathrm{CaCO}_{3}$ present initially. The amounts of $\mathrm{CO}_{2}$ desorbed from the samples $\mathrm{A}, \mathrm{B}$, and $\mathrm{C}$ are $4,3.8$, and $2.8 \mathrm{mg}$, respectively, equivalent with $0.66,0.61$, and $0.39 \mathrm{gCO}_{2} / \mathrm{g}_{\mathrm{CaO}}$, respectively. The amounts of $\mathrm{CO}_{2}$ decrease in the same order as surface area. It can be estimated that the thickness of the $\mathrm{CaCO}_{3}$ layer is in the order of $30 \mathrm{~nm}$ for all three sample. This is consistent with the observation that the maximum $\mathrm{CO}_{2}$ concentration during decomposition experiments, between 900 to 1700 ppm, which is significantly lower than the 7000 ppm thermodynamic equilibrium $\mathrm{CO}_{2}$ concentration at $630{ }^{\circ} \mathrm{C}$ [50]. Consequently, the $\mathrm{CO}_{2}$ concentration is determined by kinetics, instead of thermodynamics, and thus also by the surface area.

Figure 3 presents the effect of plasma power, measured with a Lissajous plot (see Appendix B), on the decomposition of carbonated sample C. No plasma was applied during the first two minutes and $\mathrm{CO}_{2}$ is the only product observed, while in the presence of plasma $\mathrm{CO}$ and $\mathrm{O}_{2}$ are also produced, next to $\mathrm{CO}_{2}$. Every two minutes a different voltage is applied, and the power is measured after ca. 1 minute. Changing the plasma power causes a fast response of the $\mathrm{CO}$ concentration in the order 
of seconds, while the $\mathrm{CO}_{2}$ concentration needs typically a minute to stabilize. The $\mathrm{O}_{2}$ concentration shows a delay; this effect is not understood at this time, but it may be speculated that interaction with $\mathrm{CaO}$ is responsible. Figure 3 shows that steady-state decomposition was achieved for the two lower plasma power values. The highest power setting of $9.6 \mathrm{~W}$ caused exhaustion so that the product concentrations are likely to be underestimated. Additional experiments were performed at constant maximum power as shown in Figure 4. Two experiments were performed at $2.1 \mathrm{~W}$ and demonstrate a reproducibility within $\pm 5 \%$, even though plasma was applied with a $1.5 \mathrm{~min}$ delay in the second experiment (Figure $4 \mathrm{~b}$ ). Figure $4 \mathrm{c}$ is performed at $4.4 \mathrm{~W}$, showing a higher decomposition rate and shorter steady state duration. Therefore, the power was not further increased for this sample and in general the maximum power was limited to $5.1 \mathrm{~W}$.

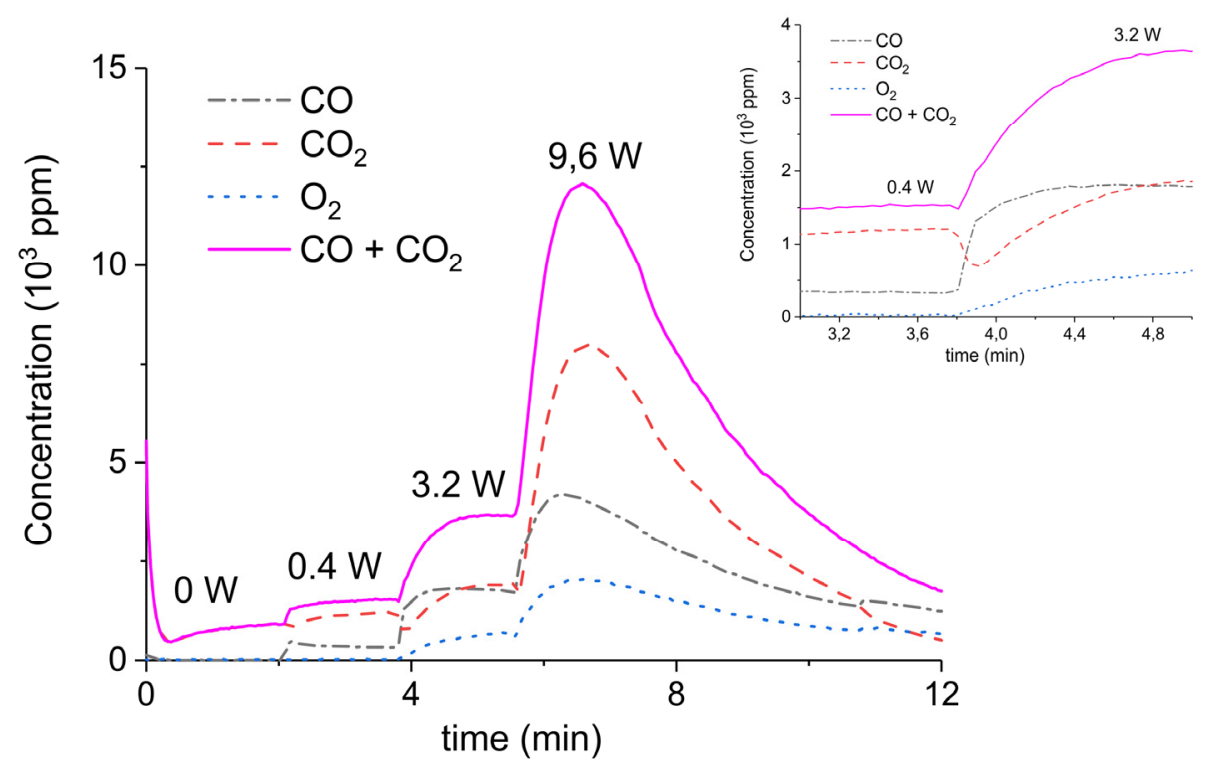

Figure 3. Concentration of the products of $\mathrm{CaCO}_{3}$ decomposition (sample $\mathrm{C}$ ) as function of time at $630{ }^{\circ} \mathrm{C}$ in pure argon, flow rate of $30 \mathrm{~mL} / \mathrm{min}$, plasma power is changed every $2 \mathrm{~min}$ with values of 0 , $0.4,3.2$, and $9.6 \mathrm{~W}$.

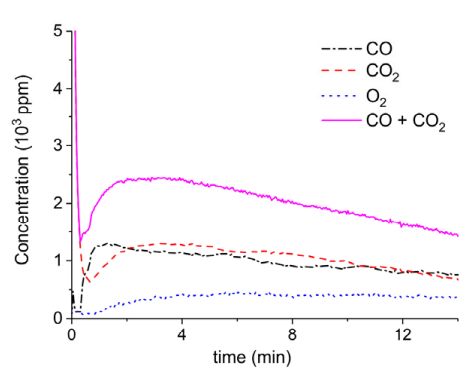

(a)

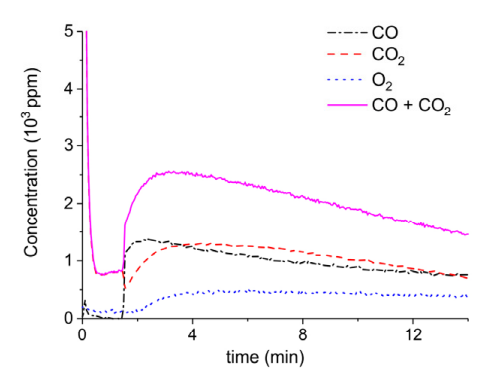

(b)

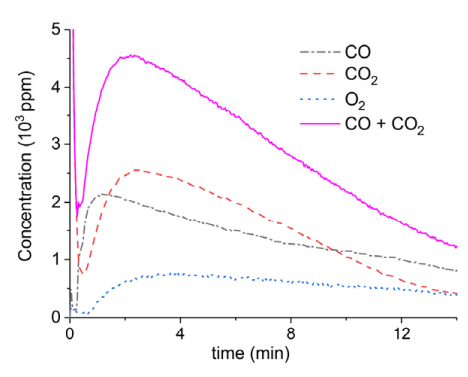

(c)

Figure 4. Concentration of the products of $\mathrm{CaCO}_{3}$ decomposition (sample $\mathrm{C}$ ) as function of time at $630{ }^{\circ} \mathrm{C}$ in pure argon, flow rate of $30 \mathrm{~mL} / \mathrm{min}$, plasma power is $2.1 \mathrm{~W}(\mathbf{a}, \mathbf{b})$ and $4.4 \mathrm{~W}$ (c). Plasma is turned on at the beginning of decomposition $(a, c)$ or after $1.5 \mathrm{~min}(\mathrm{~b})$.

Figure 5 shows three typical results on the effect of the specific surface area on the decomposition at $2.1 \mathrm{~W}$ plasma power, by comparing the samples A (ex calcium gluconate, Figure 6a), B (ex calcium ascorbate, Figure $6 \mathrm{~b}$ ), and C (ex calcium carbonate Figure $6 \mathrm{c}$ ), keeping particle size constant (250-300 $\mu \mathrm{m}$ ). The total decomposition rate, as calculated based on the sum of the rates of formation of $\mathrm{CO}$ and $\mathrm{CO}_{2}$, seems to increase with increasing specific surface area, as also observed in the absence of plasma. During the decomposition of sample B, the power has been turned off after 9 min, resulting in a rapid decrease in the $\mathrm{CO}$ and $\mathrm{CO}+\mathrm{CO}_{2}$ concentrations. Figure 6 presents all data on 
the decomposition rate measured on the three samples when changing the plasma power, showing that the rate of decomposition at the same power is significantly lower for the sample with the lowest specific surface area. The difference between sample A and B is not larger than experimental scatter, although the data suggest a slightly higher rate for sample A.

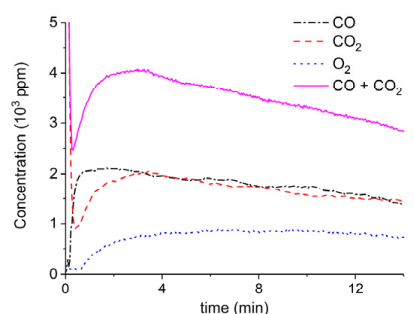

(a)

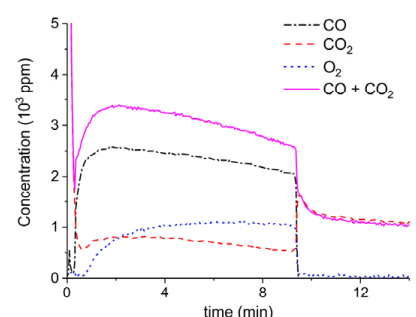

(b)

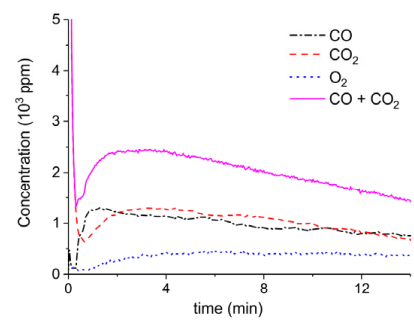

(c)

Figure 5. Concentration of the products of decomposition of sample A (a), sample B (b), and sample C (c), with a temperature of $630{ }^{\circ} \mathrm{C}$ in pure argon and flow rate of $30 \mathrm{~mL} / \mathrm{min}$; plasma power is $2.1 \pm$ $0.1 \mathrm{~W}$.

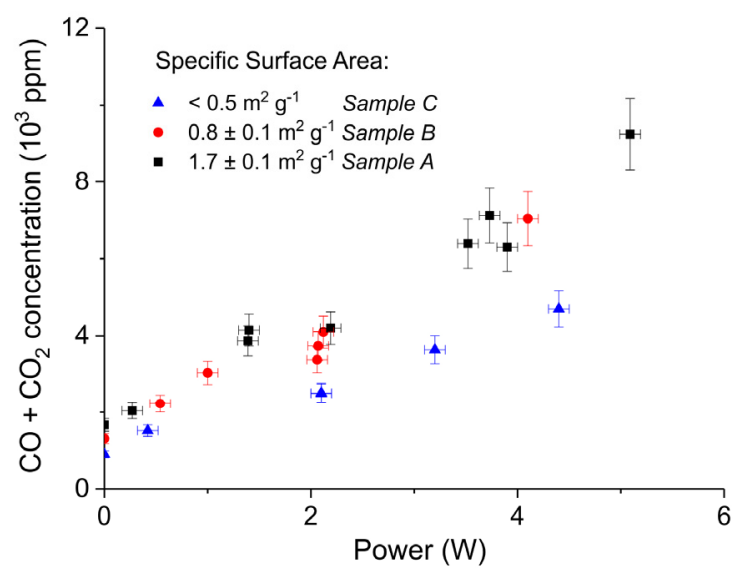

Figure 6. Sum of $\mathrm{CO}_{2}$ and $\mathrm{CO}$ concentrations plotted as function of power obtained during decomposition of $\mathrm{CaCO}_{3}$ samples $\mathrm{A}, \mathrm{B}$, and $\mathrm{C}$ with different surface areas; all the experiments performed at $630^{\circ} \mathrm{C}$, in pure argon, and flow rate $30 \mathrm{~mL} / \mathrm{min}$.

Figure 7 shows the influence of particles size on $\mathrm{CaCO}_{3}$ decomposition by comparing sample $\mathrm{C}$

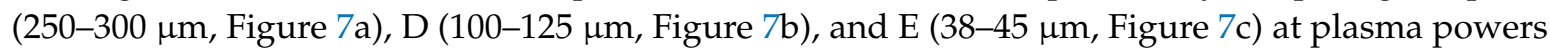
varying between 1.3 and $2.1 \mathrm{~W}$. Figure $5 \mathrm{~d}$ shows details on the response time after switching on the plasma for the three samples. The time to reach steady state is 50,40 , and 10 seconds for samples $C, D$, and $\mathrm{E}$, respectively. These times are in reasonable agreement with the Fourier times of $\mathrm{CaCO}_{3}$ particles of these sizes. The different powers do not allow direct comparison of the decomposition rates. Instead, the effect of plasma power on the decomposition rate for samples C, D, and E is presented in Figure 8, showing that the particle size has no effect on the decomposition rate within experimental error. All the experiments addressed in Figures 6 and 8 are shown in detail in Figures A1-A6 in Appendix A.

Figure 9 shows the results of a series of plasma enhanced decomposition experiments in the presence $\mathrm{CO}_{2}$ in the feed gas, measured on sample $\mathrm{C}$. All experiments were done with one sample by performing 22 carbonation and decomposition cycles. The stability of the sample was verified by repeating decomposition measurements in the absence of plasma, demonstrating invariable results within 5\% as shown in Figure A15 in Appendix A. 


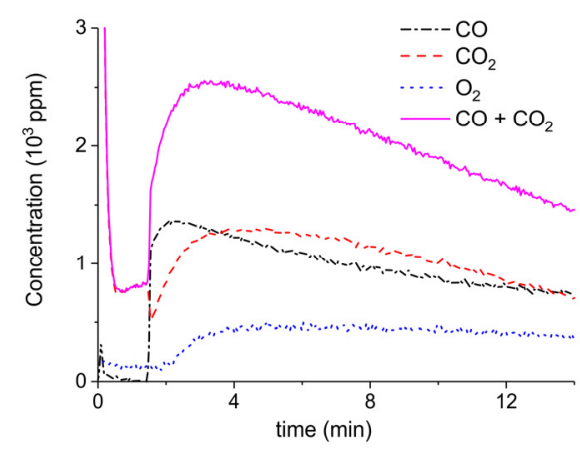

(a)

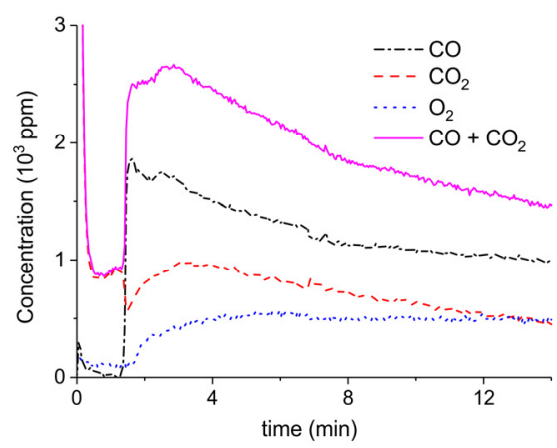

(c)

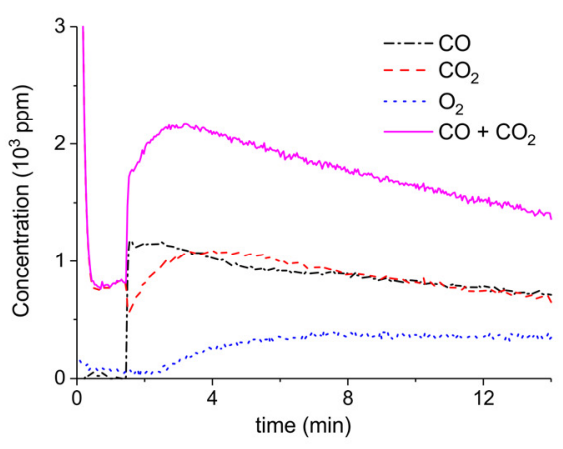

(b)

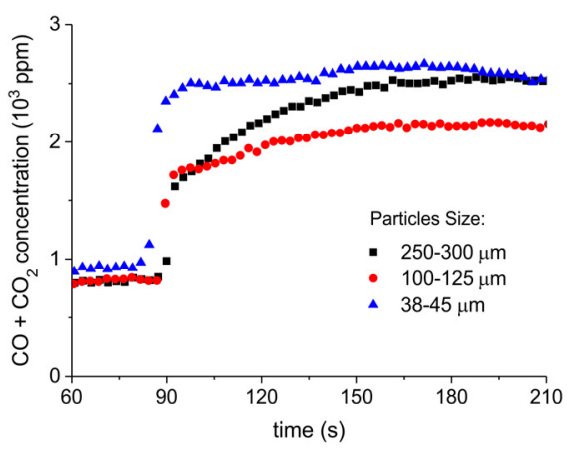

(d)

Figure 7. Concentration of the products of decomposition of sample C (a), sample D (b), and sample E (c) as function of time with a temperature of $630^{\circ} \mathrm{C}$ in pure argon and flow rate of $30 \mathrm{~mL} / \mathrm{min}$; plasma power is $2.1 \mathrm{~W}$ for sample $\mathrm{C}, 1.3 \mathrm{~W}$ for sample $\mathrm{D}$, and $1.7 \mathrm{~W}$ for sample $\mathrm{E}$. (d) Initial response of $\mathrm{CO}+$ $\mathrm{CO}_{2}$ concentration after activating the plasma for all three samples.

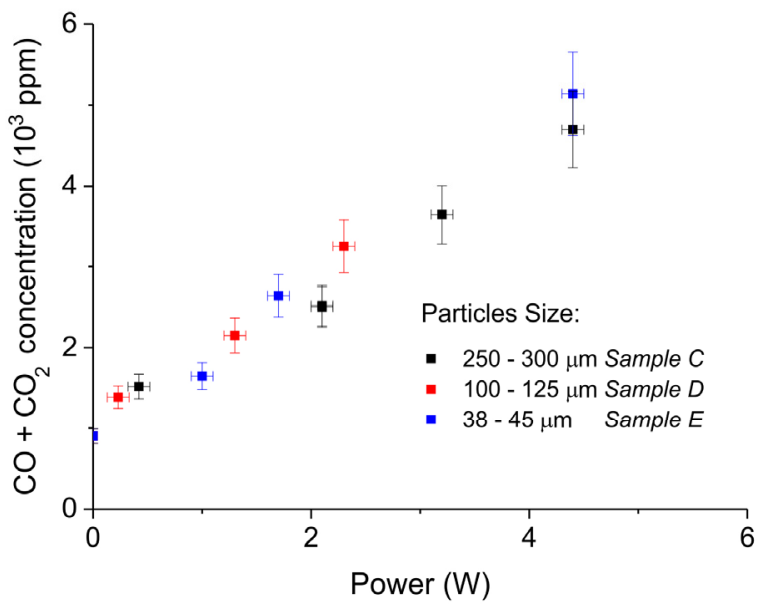

Figure 8. Sum of $\mathrm{CO}_{2}$ and $\mathrm{CO}$ concentrations as function of power during decomposition of $\mathrm{CaCO}_{3}$ samples with different particles size (samples C, D, and E); all the experiments were performed at $630{ }^{\circ} \mathrm{C}$, in pure argon, and at a flow rate $30 \mathrm{~mL} / \mathrm{min}$. 


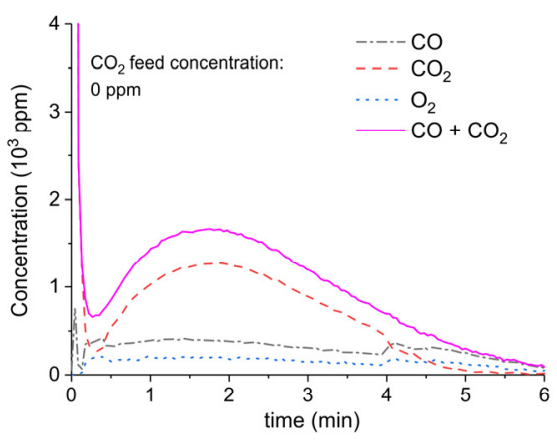

(a)

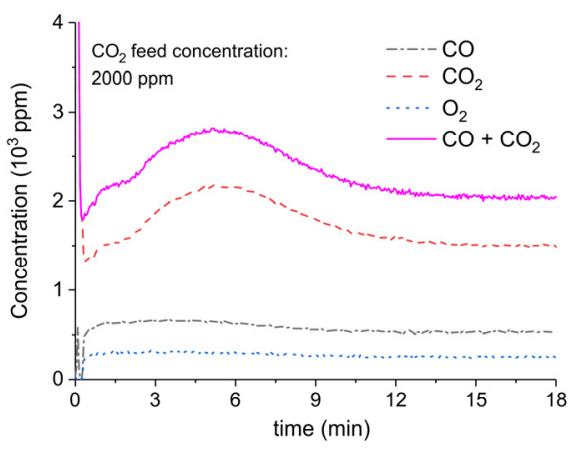

(c)

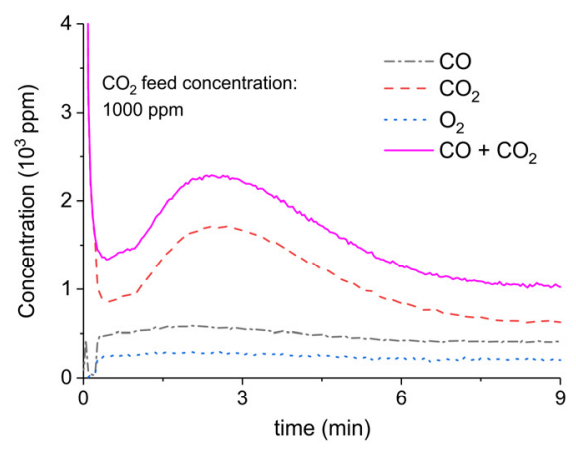

(b)

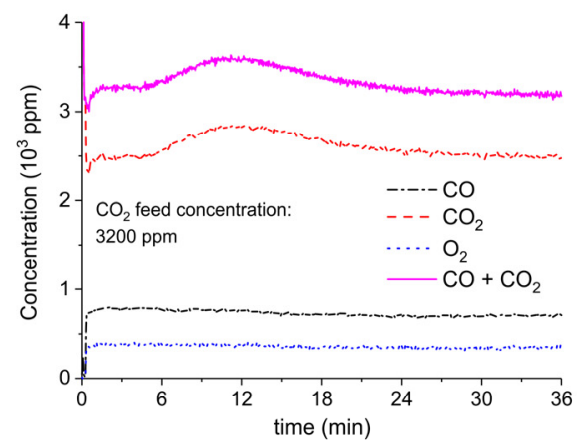

(d)

Figure 9. $\mathrm{CO}+\mathrm{CO}_{2}$ (solid line), $\mathrm{CO}_{2}$ (dashed line), $\mathrm{CO}$ (dash-dotted line), and $\mathrm{O}_{2}$ concentrations monitored by mass spectrometry during $\mathrm{CaCO}_{3}$ decomposition in different $\mathrm{CO}_{2}$ feed concentrations in Ar and different plasma power. The amount of $\mathrm{CaO}$ is $6 \mathrm{mg}$, temperature is $630{ }^{\circ} \mathrm{C}$, and the flow rate is $90 \mathrm{~mL} \mathrm{~min}^{-1}$. The fed $\mathrm{CO}_{2}$ concentration is $0 \mathrm{ppm}(\mathbf{a}), 1000 \mathrm{ppm}(\mathbf{b}), 2000 \mathrm{ppm}(\mathbf{c})$, and $3200 \mathrm{ppm}(\mathbf{d})$. The plasma power is $1.5 \mathrm{~W}(\mathrm{a}), 1.3 \mathrm{~W}(\mathrm{~b}), 1.3 \mathrm{~W}(\mathrm{c})$, and $1.5 \mathrm{~W}(\mathrm{~d})$.

Figure 9 shows the effect of $\mathrm{CO}_{2}$ in the feed on plasma-enhanced decomposition at similar plasma powers, i.e., between 1.3 and $1.5 \mathrm{~W}$. The reaction rate substantially decreases in presence of extra $\mathrm{CO}_{2}$, as can be estimated based on the sum of the concentrations of $\mathrm{CO}$ and $\mathrm{CO}_{2}$ minus the $\mathrm{CO}_{2}$ concentration at the inlet. Furthermore, the $\mathrm{CO}$ concentration increases with increasing $\mathrm{CO}_{2}$ concentration.

In order to correct for the differences in power, additional experiments at other plasma powers were performed as shown in Figures A6-A9 in Appendix A and the results allowed interpolation of the $\mathrm{CO}$ and $\mathrm{CO}_{2}$ values to $1.5 \mathrm{~W}$ plasma power, resulting in Figure 10. As the $\mathrm{CO}_{2}$ concentration varies along the axis of the reactor, an averaged value is calculated according to Equation (1):

$$
\left[\mathrm{CO}_{2}\right]_{\text {ave }}=\frac{\left[\mathrm{CO}_{2}\right]_{\text {in }}+\left[\mathrm{CO}_{2}\right]_{\text {out }}}{2}
$$




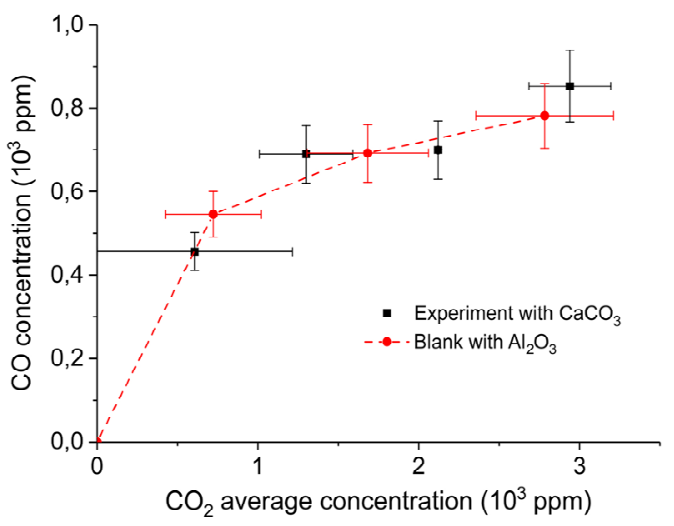

Figure 10. $\mathrm{CO}$ outlet concentration vs. $\mathrm{CO}_{2}$ average concentration obtained in a packed bed of $10 \mathrm{mg} \mathrm{CaCO}$ and $90 \mathrm{mg} \mathrm{Al}_{2} \mathrm{O}_{3}$ at $630{ }^{\circ} \mathrm{C}$ with different $\mathrm{CO}_{2}$ concentrations in Ar and a flow rate of $90 \mathrm{~mL} / \mathrm{min}$ (squares); all results interpolated to $1.5 \mathrm{~W}$ plasma power. The same experiment was also performed with $100 \mathrm{mg} \mathrm{Al}{ }_{2} \mathrm{O}_{3}$ only (circles). Error margins of the $\mathrm{CO}$ concentration are provided, as well as the window of the $\mathrm{CO}_{2}$ concentrations (note these are not error margins).

The spread in the $\mathrm{CO}_{2}$ concentration provides the window of concentrations occurring along the axis of the reactor; note this is not an error margin. Figure 11 confirms that the $\mathrm{CO}$ concentration indeed increases with increasing $\mathrm{CO}_{2}$ concentration in the gas phase and this is observed for both $\mathrm{CaCO}_{3}$ as well as the blank experiment with $\alpha-\mathrm{Al}_{2} \mathrm{O}_{3}$ only, which is shown in Figure A10 in Appendix A.

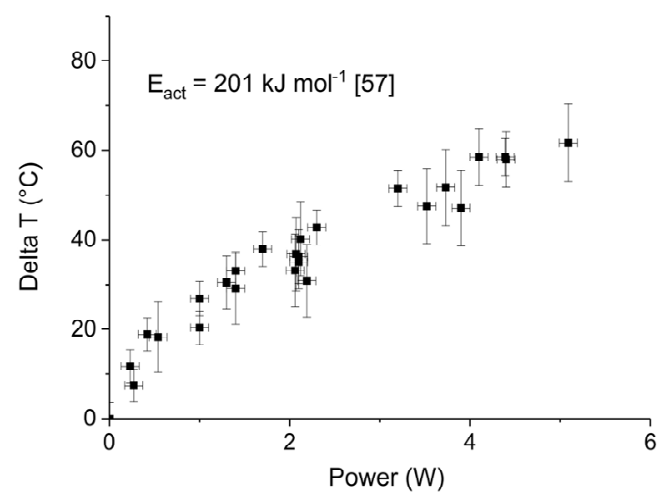

Figure 11. Average increase of temperature in the plasma zone as function of power during the $\mathrm{CaCO}_{3}$ decomposition previously shown.

\section{Discussion}

Scheme 1 presents a simple reaction scheme describing $\mathrm{CaCO}_{3}$ decomposition, both in the absence and presence of plasma. Thermal decomposition without plasma involves exclusively $\mathrm{R}_{1}$ (solid arrow), whereas in the presence of plasma both $R_{2}$ and $R_{3}$ might contribute. The observed enhancement of decomposition by plasma might be caused by plasma chemistry according $R_{2}$ and/or by enhancing $R_{1}$ via increasing temperature, as will be discussed below. Furthermore, we will discuss whether $R_{2}$ or $R_{3}$ is responsible for the formation of $\mathrm{CO}$.

$$
\begin{array}{ccc}
\mathrm{CaCO}_{3(s)} \stackrel{R_{1}}{\longrightarrow} \mathrm{CaO}_{(s)}+\mathrm{CO}_{2(g)} \\
\ddots & R_{3} \\
& \ddots & \mathrm{CaO}_{(s)}+\mathrm{CO}_{(g)}+\frac{1}{2} \mathrm{O}_{2(g)}
\end{array}
$$

Scheme 1. $\mathrm{CaCO}_{3}$ decomposition in Ar plasma. 


\subsection{Formation of $\mathrm{CO}$}

Figure 10 shows that the $\mathrm{CO}$ formation rate is not affected by the presence of $\mathrm{CaCO}_{3}$ in the plasma at low $\mathrm{CO}_{2}$ feed concentrations. It is enhanced by feeding additional $\mathrm{CO}_{2}$. Hence, we conclude that $\mathrm{CO}$ formation occurs only in the gas phase $\left(\mathrm{R}_{3}\right)$ and not on the $\mathrm{CaCO}_{3}$ surface $\left(\mathrm{R}_{2}\right)$. The trend in Figure 11 also indicates that the order of $\mathrm{CO}$ formation in the $\mathrm{CO}_{2}$ concentration is clearly smaller than one. This is qualitatively in line with the results of Ramakers et al. [25] and Butterworth et al. [27], reporting that Ar can enhance the activation of $\mathrm{CO}_{2}$, which is attributed to the fact that the electron density is enhanced because $\mathrm{Ar}$ is much easier ionized than $\mathrm{CO}_{2}$. On the other hand, one may also speculate that higher $\mathrm{CO}_{2}$ concentration increases the probability of recombination of $\mathrm{CO}$ and $\mathrm{O}$, quenching the reaction.

The formation of $\mathrm{CO}$ responds extremely fast to switching the plasma on, as can be seen in Figures 3-5 and Figure 7, much faster than the $\mathrm{CO}_{2}$ response as will be discussed below. This is in line with the conclusion that $\mathrm{CO}$ formation is plasma controlled. In cases when $\mathrm{CO}_{2}$ concentration increase slowly in time (Figures 4 and 5), it can be seen that the $\mathrm{CO}$ concentration follows, which is in line with the conclusion that the consecutive pathway $R_{3}$ is dominant over $R_{2}$.

\subsection{Thermal Effect or Plasma Chemistry?}

The decomposition rate at a fixed power depends on the total surface area, as can be observed from Figure 6. On the other hand, the decomposition rate remains constant within experimental error when varying the particles size and consequently the external surface area, as shown in Figure 8. Therefore, the external surface area has no influence on the rate of decomposition at any power. According to the Paschen law, typically plasma cannot exist in pores smaller than $6 \mu \mathrm{m}$, implying that any plasma chemistry on the surface of $\mathrm{CaCO}_{3}$ can exclusively contribute at the external surface of the particles. Recent work [56] revealed that penetration into relatively large pores is possible; however, the pores in $\mathrm{CaCO}_{3}$ are much smaller, the electrical field is two orders of magnitude lower compared to [56], and the calculated penetration depth is limited to $5 \mu \mathrm{m}$, which is much smaller than the particle size used. Therefore, it seems reasonable to assume that penetration of plasma in this study is negligible. As the external surface area has no significant effect, we conclude that $R_{2}$ does not contribute. The enhancing effect of plasma power on the decomposition rate, as well as the observation that increasing the specific surface area increases the rate of decomposition (both in Figure 6), both suggest that plasma induced temperature increase is responsible for the increase in the decomposition rate. In fact, this is a result that can be expected operating with an Ar plasma because a chemical reaction between $\mathrm{Ar}$ ions and $\mathrm{CaCO}_{3}$ would not be expected. Work on DBD plasmas containing $\mathrm{H}_{2}$ and $\mathrm{H}_{2} \mathrm{O}$ is ongoing in which plasma induced chemical reactions are much more likely, in which we will use the methodology developed in this work.

Figure 11 shows the apparent temperature increase, as estimated based on the temperature that would be required to account for the increase in decomposition rate, based on the kinetics of the decomposition reaction [57]. Remarkably, all observations converge to a single line independent of both surface area and particle size. The order of magnitude of the temperature increase is quite similar to results reported in literature. Typical temperatures estimated in DBD plasmas range up to typically $200 \mathrm{~K}[17,23,41-48]$. It should be noted that determination of the temperature is cumbersome, e.g., the temperature of the exiting gas provides only a minimum value because of rapid heat exchange between small reactors and environment, whereas infrared cameras and UV-Vis spectroscopy measurements have limited accuracy. Nevertheless, the order of magnitude agrees well with our observations. In short, although experimental details vary, a temperature increase of $50{ }^{\circ} \mathrm{C}$ due to $4 \mathrm{~W}$ plasma power input is concluded.

The temperature regulation of the oven played an important role in our study. It stabilized the temperature at a few millimeters outside the low voltage electrode at $630{ }^{\circ} \mathrm{C}$. Therefore, any power input from the plasma will result in a decrease of the electrical power to the oven. Hence, the 
temperature effect of the plasma is actually larger than estimated above, in contrast to all experiments performed at room temperature without any kind of temperature control.

The conclusion that thermal effects are dominant is further supported by the fact that the typical response time of the decomposition rate is in the order of one minute for large particles and somewhat faster for small particles (Figures 4 and $8 \mathrm{~d}$ ). The order of magnitude agrees well with the Fourier time of $\mathrm{CaCO}_{3}$ particles of the sizes used. In any case, the response times are longer than response times observed for $\mathrm{CO}$ formation, as discussed above, which is in line with the conclusion that decomposition is thermally controlled, whereas $\mathrm{CO}_{2}$ dissociation is obviously plasma controlled.

The conclusion is also reinforced by the fact that the sum of $\mathrm{CO}_{2}$ and $\mathrm{CO}$ concentrations obtained by decomposition of sample $\mathrm{C}$ at $630^{\circ} \mathrm{C}$ and $3.2 \mathrm{~W}$ plasma power corresponds to the $\mathrm{CO}_{2}$ concentration obtained by decomposition at $680^{\circ} \mathrm{C}$ (i.e., increasing the temperature of $50^{\circ} \mathrm{C}$ as calculated in Figure 11) without plasma of the same sample, as observed by comparing Figures A3a and A11 in Appendix A.

The proposed method is validated, since it enables to distinguish between thermal and plasma chemistry effect on the decomposition rate. This method is applicable to other systems in which a plasma is in contact with a fixed bed of porous particles, including supported catalysts. It should be noted that in general the increase in gas temperature in a DBD plasma cannot be neglected, as done frequently in many studies. Second, only the external surface of catalysts particles interacts with plasma: plasma-catalyst synergy is therefore maximal for nonporous catalytic materials. Further work is currently ongoing to apply this method for $\mathrm{CaCO}_{3}$ decomposition in more reactive plasma, e.g., $\mathrm{H}_{2}$ plasma, as well as for plasma catalytic conversions.

\section{Materials and Methods}

\subsection{Plasma Reactor}

Figure 12 shows a schematic representation of the equipment used to measure plasma enhanced decomposition of $\mathrm{CaCO}_{3}$. The fixed bed reactor is fed with either pure Ar, or a mixture of Ar containing $5 \% \mathrm{CO}_{2}$. The temperature of the oven is controlled with a Euro-Therm controller with an accuracy of $\pm 0.5^{\circ} \mathrm{C}$ between room temperature and $1000{ }^{\circ} \mathrm{C}$. The isothermal zone is $8 \mathrm{~cm}$ long at $900{ }^{\circ} \mathrm{C}$, defined as the part of the reactor with less than $\pm 1{ }^{\circ} \mathrm{C}$ temperature variation. A Quadrupole Mass Spectrometer (MS) measures the composition of the gas downstream of the reactor. The MS signal for $\mathrm{CO}_{2}(44 \mathrm{~m} / \mathrm{e})$ is calibrated between $0.16 \%$ and $5 \% \mathrm{CO}_{2}$, resulting in a linear relationship as shown in Figure A14. The reactor is a $4 \mathrm{~mm}$ inner- and $6 \mathrm{~mm}$ outer diameter quartz tube. The inner electrode is a stainless-steel rod of $1 \mathrm{~mm}$ diameter placed coaxially in the center of the reactor section. The outer electrode is a $1 \mathrm{~cm}$ long stainless-steel tube with $6 \mathrm{~mm}$ inner diameter, enclosing a plasma zone of $0.035 \mathrm{~cm}^{3}$ in volume. The amount of $\mathrm{CaCO}_{3}$ sample was limited to $10.5 \pm 0.3 \mathrm{mg}$ in order to prevent $\mathrm{CO}_{2}$ concentrations approaching thermodynamic equilibrium, thus minimizing reabsorption of $\mathrm{CO}_{2}$. The $10 \mathrm{mg}$ sample was mixed with $90 \mathrm{mg} \alpha-\mathrm{Al}_{2} \mathrm{O}_{3}$, filling the plasma zone completely and preventing any bypassing. An AC voltage of up to $10 \mathrm{kV}$ peak to peak was applied to the inner electrode with a frequency of $23.5 \mathrm{kHz}$ using a PMV 500-4000 power supply, while the outer electrode is connected to the ground via a probe capacitor of capacity $4 \mathrm{nF}$. The power of the plasma was calculated using the Lissajous method by measuring the voltage on the inner electrode with a Tektronix P6015A high voltage probe and on the outer electrode with a TT-HV 250 voltage probe, as described in the literature [58]. A sample of Lissajous plot is shown in Figure A12 in Appendix B. 


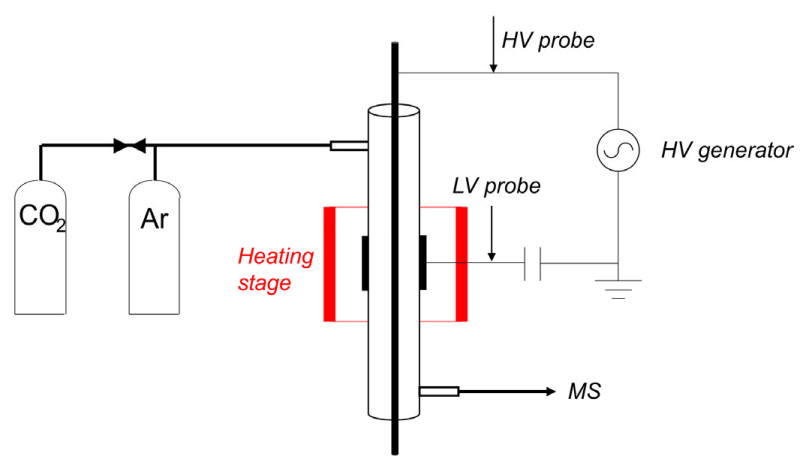

Figure 12. Schematic of the setup to study decomposition of $\mathrm{CaCO}_{3}$ in Ar plasma. The generator can provide up to $30 \mathrm{kV}$ peak to peak with a frequency range of 23.5 to $66 \mathrm{kHz}$. The plasma zone is $1 \mathrm{~cm}$ long and the reactor is a quartz tube with $6 \mathrm{~mm}$ outer diameter and $4 \mathrm{~mm}$ inner diameter. The inner electrode is a stainless-steel rod of $1 \mathrm{~mm}$ diameter.

\subsection{Calcium Oxides Preparation}

Three different precursors have been used to synthesize calcium oxide, respectively (batch I) calcium L-ascorbate-di-hydrate (99\%, Sigma-Aldrich, St. Louis, MO, USA), (batch II) calcium D-gluconate-monohydrate (99\%, Alfa Aesar, Haverhill, MA, USA), and (batch III) calcium carbonate (99\%, Sigma-Aldrich, St. Louis, MO, USA). The precursors were calcined in $20 \% \mathrm{O}_{2}$ in $\mathrm{N}_{2}$ at atmospheric pressure, heating the sample to $900{ }^{\circ} \mathrm{C}$ (heating rate $15^{\circ} \mathrm{C} / \mathrm{min}$ ), and keeping the temperature at $900{ }^{\circ} \mathrm{C}$ for $3 \mathrm{~h}$. The calcined products were pelletized (pressure $160 \mathrm{bar}$ ), crushed and sieved in different particle size range: $250-300 \mu \mathrm{m}, 100-125 \mu \mathrm{m}$, and $38-45 \mu \mathrm{m}$.

\subsection{Carbonation}

Five $\mathrm{CaCO}_{3}$ samples have been produced via carbonation of $\mathrm{CaO}$. The oxide synthesized from calcium ascorbate (batch II) has been treated in situ with $5 \% \mathrm{CO}_{2}$ in $\mathrm{Ar}$ at $630{ }^{\circ} \mathrm{C}$ for $4 \mathrm{~h}$ (heating rate $15{ }^{\circ} \mathrm{C} / \mathrm{min}$ ), the other two batches I and III were treated in a calcination oven with $20 \% \mathrm{CO}_{2}$ in $\mathrm{N}_{2}$ at $630{ }^{\circ} \mathrm{C}$ for $5 \mathrm{~h}$ (heating rate $15^{\circ} \mathrm{C} / \mathrm{min}$ ). The oxide synthesized from calcium carbonate (III) was consecutively sintered in pure $\mathrm{CO}_{2}$ at $900{ }^{\circ} \mathrm{C}$ for $24 \mathrm{~h}$ (heating rate $15^{\circ} \mathrm{C} / \mathrm{min}$ ), as summarized in Table 1 . The resulting three samples (A, B, and C) were crushed and sieved, obtaining particles sizes in the range between 250 and $300 \mu \mathrm{m}$. The material made from $\mathrm{CaCO}_{3}$ was also obtained with smaller particles, between 100 and $125 \mu \mathrm{m}$ (sample D) and between 38 and $45 \mu \mathrm{m}$ (sample E), respectively.

\subsection{Characterization}

The specific surface area, pore volume, and pore size distribution of the samples were measured both in $\mathrm{CaO}$ form as well as in $\mathrm{CaCO}_{3}$ form, after carbonation. The samples were first degassed at $300{ }^{\circ} \mathrm{C}$ in vacuum for $3 \mathrm{~h}$. The surface area was calculated based on the BET isotherm for $\mathrm{N}_{2}$ adsorption at $-196^{\circ} \mathrm{C}$ in a Tristar 3000 analyzer (Micromeritics, Norcross, GA, USA). The pore size distribution was measured by $\mathrm{Hg}$ porosimetry. The chemical composition was determined with $\mathrm{X}$-ray fluorescence analysis in a S8 Tiger (Bruker, Billerica, MA, USA).

\subsection{Experimental Procedure}

The carbonated samples (ex situ) were heated up in $5 \% \mathrm{CO}_{2}$ in $\mathrm{Ar}$ to the temperature at which decomposition is to be measured, in order to prevent any premature decomposition. The decomposition reaction is initiated by switching the gas composition from $5 \% \mathrm{CO}_{2}$ to pure $\mathrm{Ar}$, at a constant flow rate of $30 \mathrm{~mL} / \mathrm{min}$. Isothermal decomposition experiments have been performed at different plasma powers by varying the applied voltage. The plasma power was varied during the experiment in case of low decomposition rates, allowing observations of steady state $\mathrm{CO}_{2}$ concentrations for each plasma power. In case $\mathrm{CaCO}_{3}$ is exhausted too fast, only one single power was 
applied. The rate of decomposition is calculated based on the sum of $\mathrm{CO}_{2}$ and $\mathrm{CO}$ concentrations in the exit of the reactor as measured with MS.

Sample C (Table 1, ex calcium carbonate, 250-300 $\mu \mathrm{m}$ ) was measured by performing 20 carbonation-decomposition cycles. The sample was recarbonated, after a decomposition experiment, in the reactor (in situ) by $\mathrm{CO}_{2}$ absorption at $630{ }^{\circ} \mathrm{C}$ in $5 \% \mathrm{CO}_{2}$ in $\mathrm{Ar}$ for $30 \mathrm{~min}$ in a constant flow of $90 \mathrm{~mL} / \mathrm{min}$. The carbonated samples were decomposed using a constant power plasma in the presence of a relatively low $\mathrm{CO}_{2}$ concentration in the feed, varied between 0 to $3200 \mathrm{ppm}$. During these 20 cycles, blank experiments were done every few cycles by decomposing in the absence of plasma, in order to ensure that the sample did not change in the course of the experiments.

Blank experiments were performed with $100 \mathrm{mg}$ of $\alpha-\mathrm{Al}_{2} \mathrm{O}_{3}$ with particles size of 250 to $300 \mu \mathrm{m}$ in the absence of any $\mathrm{CaCO}_{3}$, operating with low $\mathrm{CO}_{2}$ concentrations in the feed, i.e., 1000, 2000, and $3200 \mathrm{ppm}$. The plasma power was varied between 0 and $10 \mathrm{~W}$ and the responses of the $\mathrm{CO}$ and $\mathrm{CO}_{2}$ concentrations were measured with MS.

\section{Conclusions}

The effect of argon plasma on calcium carbonate decomposition was herein assessed by means of a comparative method which allowed us to distinguish between thermal effects and plasma chemistry, based on reaction rates and dynamics. It represents a systematic method to distinguish between thermal effects versus plasma chemistry effect in fixed DBD plasma applications. Application of a DBD Ar plasma causes two effects when decomposing $\mathrm{CaCO}_{3}$.

First, the rate of $\mathrm{CaCO}_{3}$ decomposition increases. We conclude that this effect is purely a thermal effect, based on the fact that the rate of decomposition is enhanced when the total surface area is increased, whereas the external surface area has no influence. If the contact of plasma with $\mathrm{CaCO}_{3}$ would dominate, the opposite would be expected. Furthermore, the dynamics of $\mathrm{CaCO}_{3}$ decomposition follow the dynamics of heat transfer in $\mathrm{CaCO}_{3}$ particles.

Second, plasma induces formation of $\mathrm{CO}$. We conclude that this occurs via decomposition of $\mathrm{CO}_{2}$ in the gas phase, based on the observation that the rate of $\mathrm{CO}$ formation is ruled by the $\mathrm{CO}_{2}$ concentration as well as the observation that dynamic changes are very fast, as expected for plasma effect.

Author Contributions: Conceptualization, G.G., L.L., and G. van R.; Methodology, G.G. and L.L.; Validation, G.G., L.L., and G. van R.; Formal Analysis, G.G. and L.L.; Investigation, G.G. and L.L.; Resources, L.L.; Data Curation, G.G. and L.L.; Writing-Original Draft Preparation, G.G.; Writing-Review and Editing, G.G. and L.L.; Supervision, L.L. Project Administration, G.G. and L.L.; Funding Acquisition, L.L.

Funding: This work was supported by Netherlands Organization for Scientific Research (NWO).

Acknowledgments: We acknowledge Bert Geerdink, Karin Altena-Schildkamp, and Tom Velthuizen for Technical assistance; Tom Butterworth and Floran Peeters from DIFFER for the fruitful discussions and help in understanding; Tesfaye Belete and Micheal Gleeson from DIFFER also for their fruitful discussions and critical feedback; and Vera Meyner, the technical staff of the department of Chemistry of University of Antwerp, and Frank Morssinkhof for the continuous help in material characterization.

Conflicts of Interest: The authors declare no conflict0s of interest.

\section{Appendix A.}

\section{Appendix A.1. Decomposition in Argon Plasma of All the Samples}

Figures A1-A5 show the results of all the $\mathrm{CaCO}_{3}$ decomposition experiments on samples A-E, respectively, in presence of plasma and without recycling. The results with power higher than $6 \mathrm{~W}$ and further than the second step of power have been rejected due to exhaustion. 


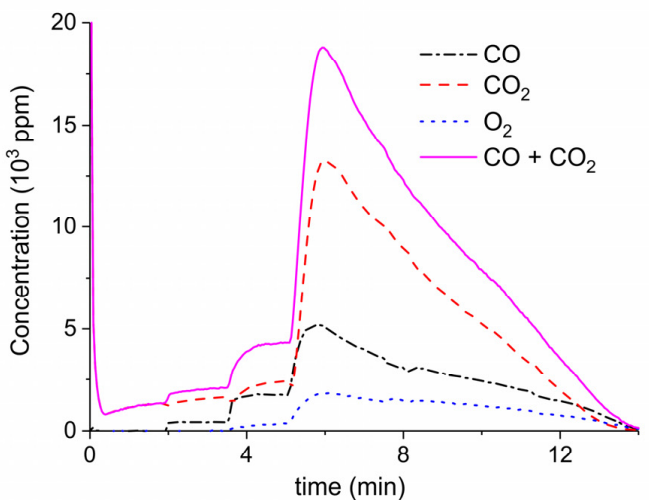

(a)

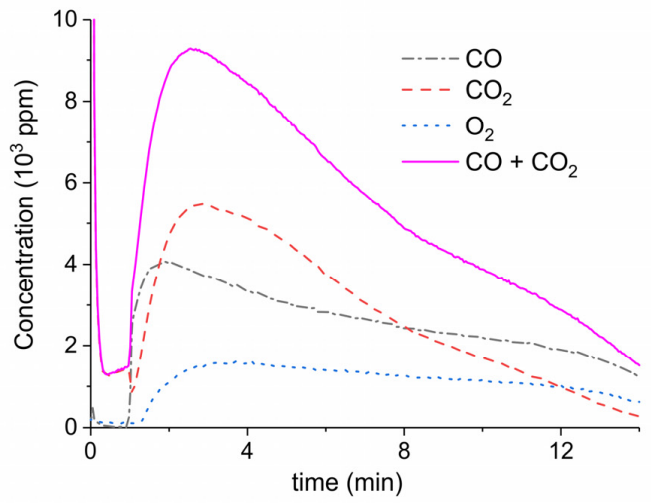

(c)

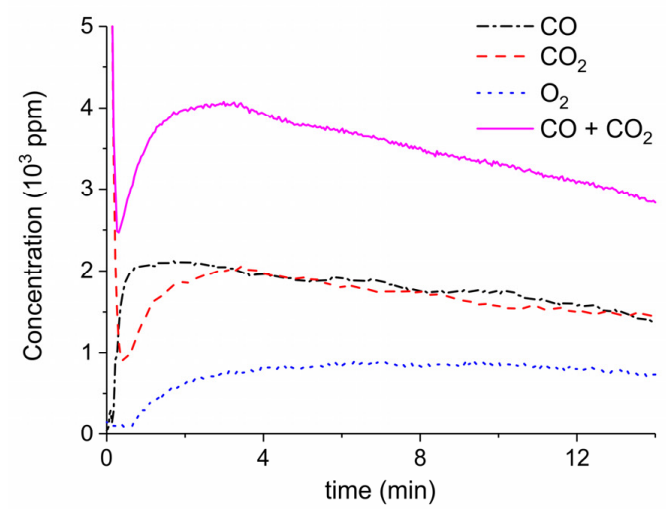

(e)

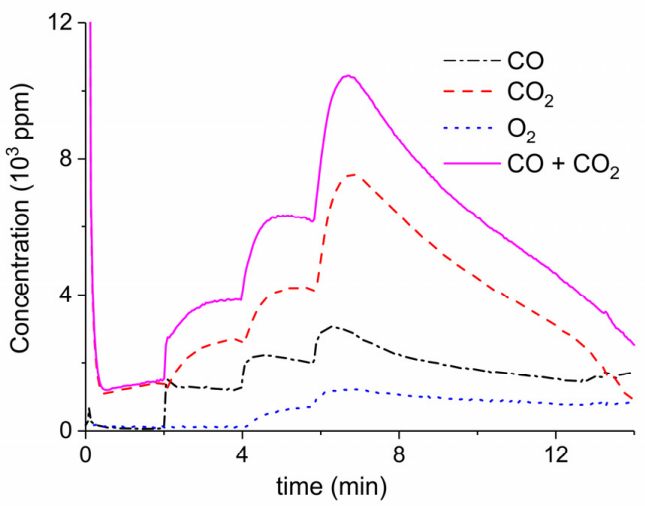

(b)

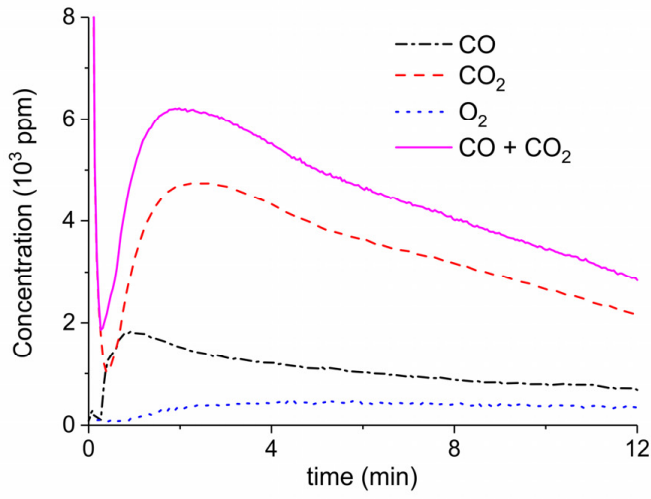

(d)

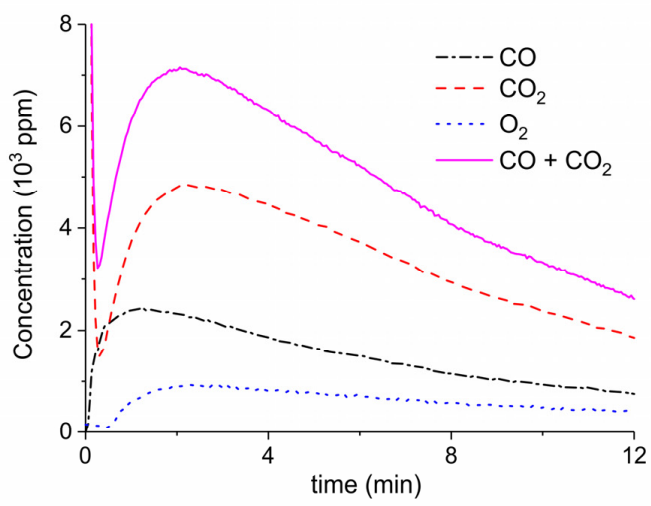

(f)

Figure A1. Concentration of the products of $\mathrm{CaCO}_{3}$ decomposition (sample A) as function of time at $630^{\circ} \mathrm{C}$ in pure argon and flow rate of $30 \mathrm{~mL} / \mathrm{min}$. Plasma power is $0.3,1.4$, and $8.4 \mathrm{~W}(\mathbf{a}) ; 1.4,3.5$, and $6.4 \mathrm{~W}(\mathbf{b}) ; 5.1 \mathrm{~W}(\mathbf{c}) ; 3.9 \mathrm{~W}(\mathbf{d}) ; 2.2 \mathrm{~W}(\mathbf{e})$; and $3.7 \mathrm{~W}(\mathbf{f})$. Plasma is turned on after $2 \mathrm{~min}$ and changed every $2 \mathrm{~min}(\mathrm{a}, \mathrm{b})$, after $1.5 \mathrm{~min}(\mathrm{c})$, or at the beginning of the decomposition $(\mathrm{d}-\mathrm{f})$. 


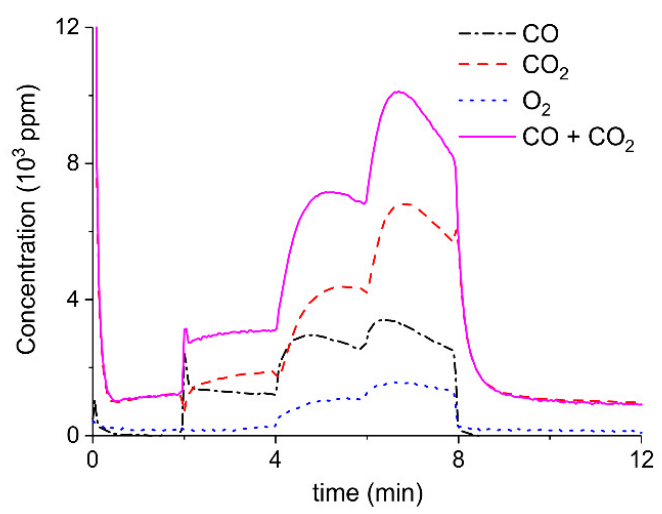

(a)

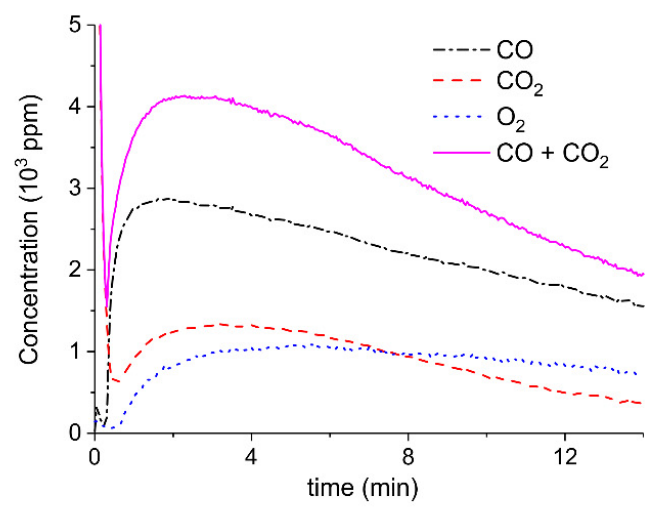

(c)

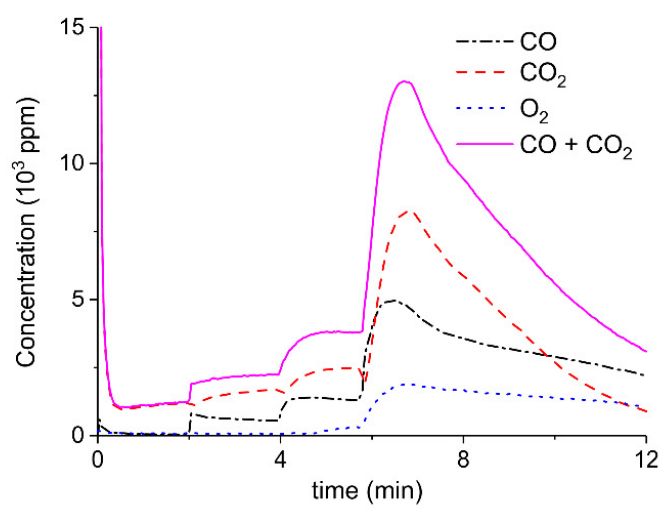

(b)

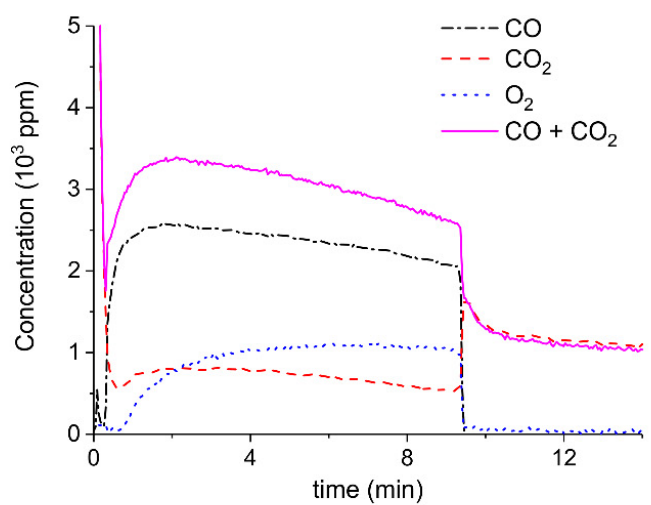

(d)

Figure A2. Concentration of the products of $\mathrm{CaCO}_{3}$ decomposition (sample $\mathrm{B}$ ) as function of time at

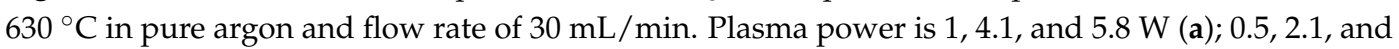
$8.5 \mathrm{~W}(\mathbf{b})$; and $2.1 \mathrm{~W}(\mathbf{c}, \mathbf{d})$. Plasma is turned on after $2 \mathrm{~min}$ and changed every $2 \mathrm{~min}(\mathrm{a}, \mathrm{b})$ or at the beginning of the decomposition $(\mathrm{c}, \mathrm{d})$.

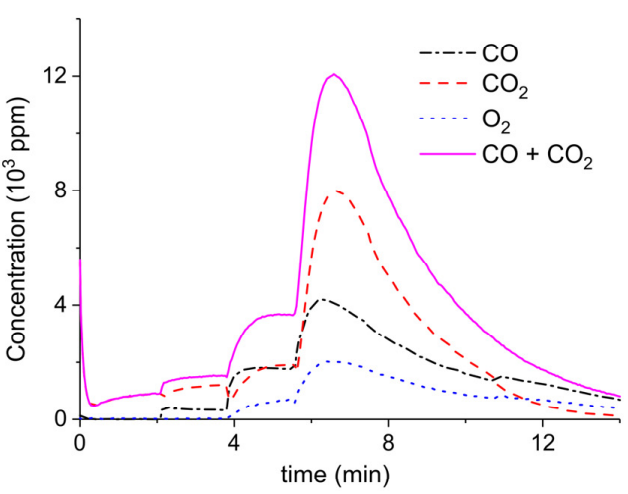

(a)

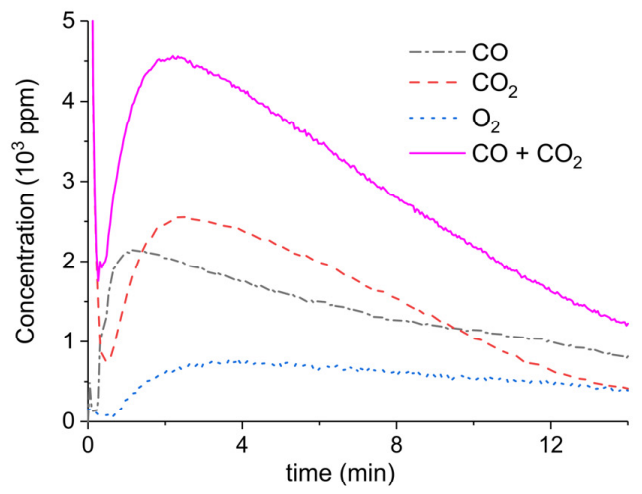

(b)

Figure A3. Cont. 


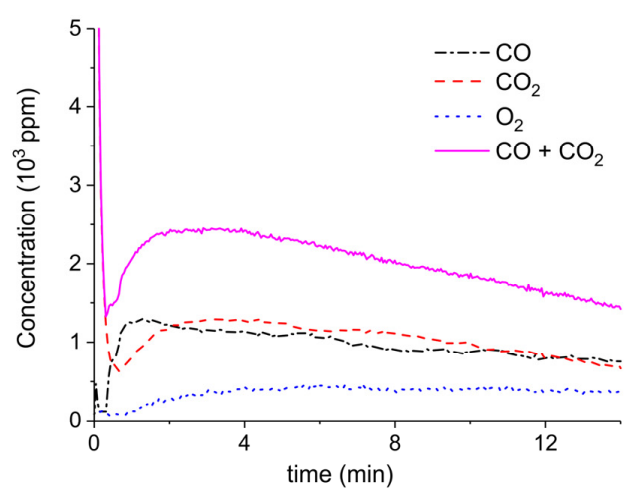

(c)

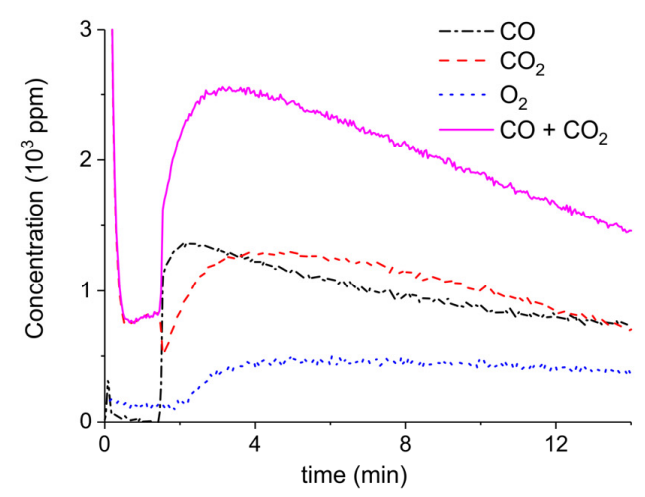

(d)

Figure A3. Concentration of the products of $\mathrm{CaCO}_{3}$ decomposition (sample $\mathrm{C}$ ) as function of time at $630{ }^{\circ} \mathrm{C}$ in pure argon and flow rate of $30 \mathrm{~mL} / \mathrm{min}$. Plasma power is $0.4,3.2$, and $9.6 \mathrm{~W}(\mathbf{a}) ; 4.4 \mathrm{~W}(\mathbf{b})$; and $2.1 \mathrm{~W}(\mathbf{c}, \mathbf{d})$. Plasma is turned on after $2 \mathrm{~min}$ and changed every $2 \mathrm{~min}$ (a) or at the beginning of the decomposition $(b, c)$ or after $1.5 \min (d)$.

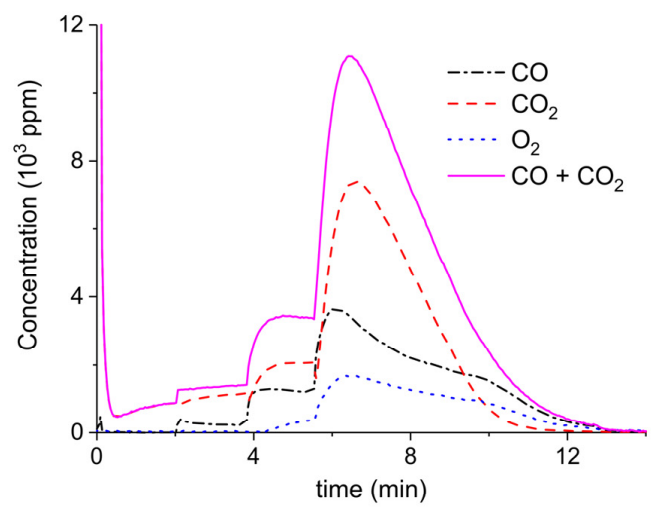

(a)

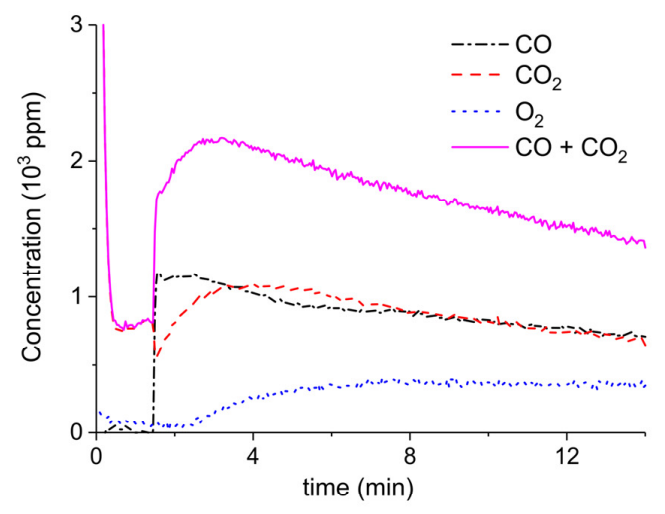

(b)

Figure A4. Concentration of the products of $\mathrm{CaCO}_{3}$ decomposition (sample D) as function of time at $630{ }^{\circ} \mathrm{C}$ in pure argon and flow rate of $30 \mathrm{~mL} / \mathrm{min}$. Plasma power is $0.2,2.3$, and $8.1 \mathrm{~W}(\mathbf{a})$ and $1.3 \mathrm{~W}(\mathbf{b})$. Plasma is turned on after $2 \mathrm{~min}$ and changed every $2 \mathrm{~min}(\mathrm{a})$ or after $1.5 \mathrm{~min}(\mathrm{~b})$.

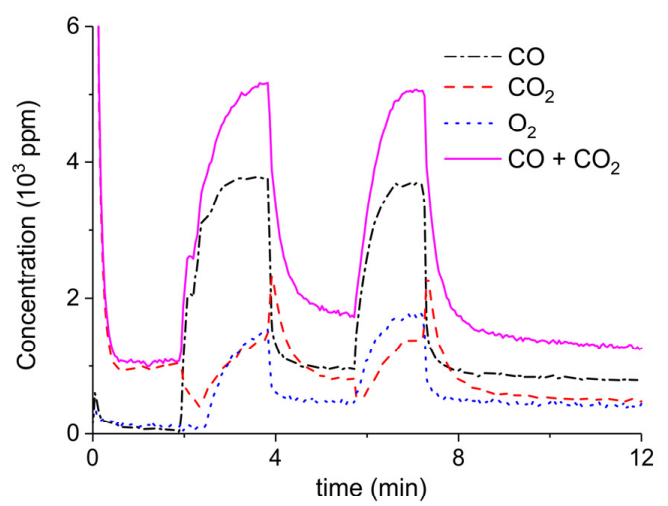

(a)

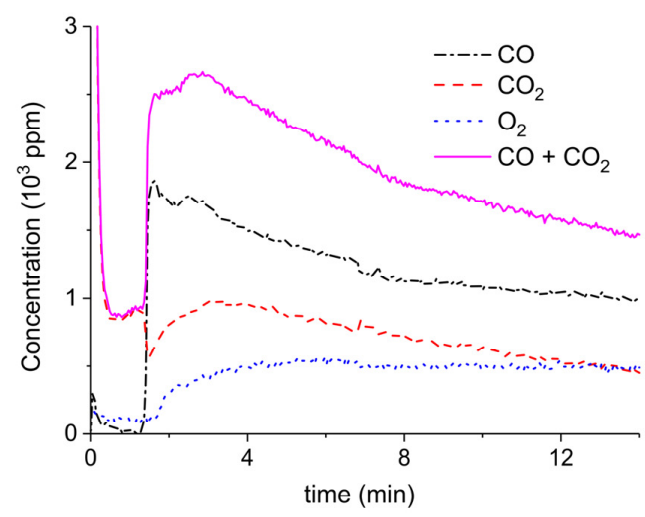

(b)

Figure A5. Concentration of the products of $\mathrm{CaCO}_{3}$ decomposition (sample $\mathrm{E}$ ) as function of time at $630^{\circ} \mathrm{C}$ in pure argon and flow rate of $30 \mathrm{~mL} / \mathrm{min}$. Plasma power is $4.4,1,4.9$, and $1 \mathrm{~W}$ (a) and $1.7 \mathrm{~W}$ (b). Plasma is turned on after $2 \mathrm{~min}$ and changed every $2 \mathrm{~min}$ (a) or after $1.5 \mathrm{~min}$ (b).

Figures A6-A9 show the results of all the $\mathrm{CaCO}_{3}$ decomposition experiments on sample $\mathrm{C}$ in presence of plasma when the sample is recycled 20 times, including experiments with extra $\mathrm{CO}_{2}$ added. 


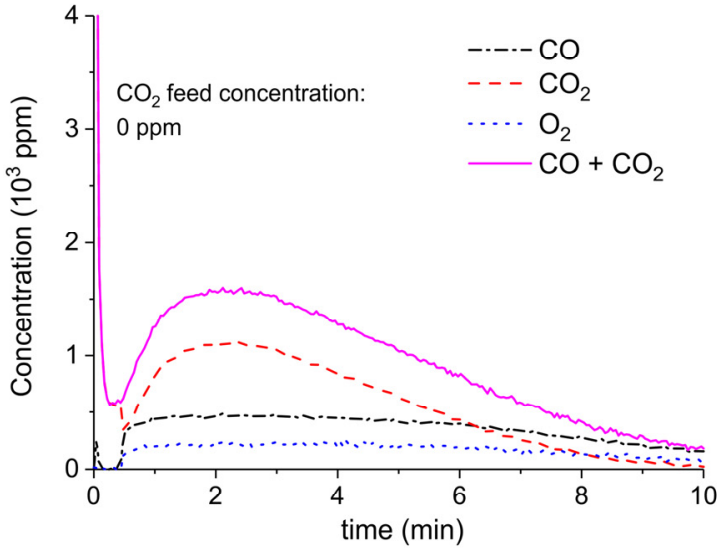

(a)

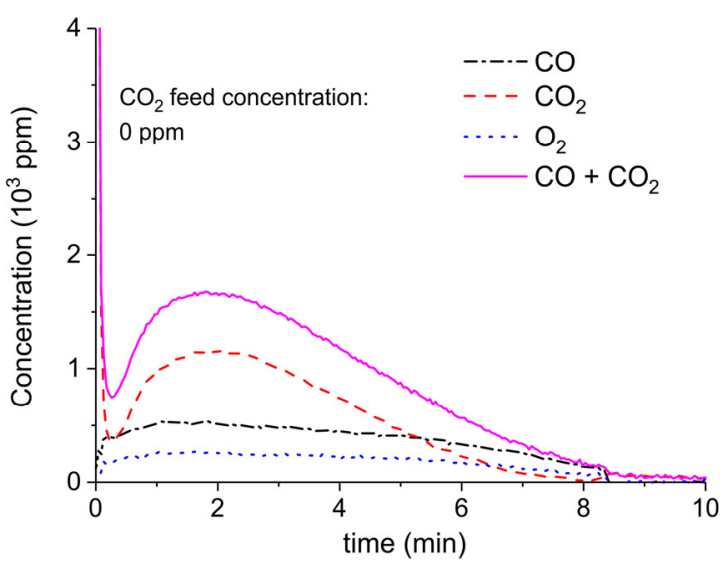

(c)

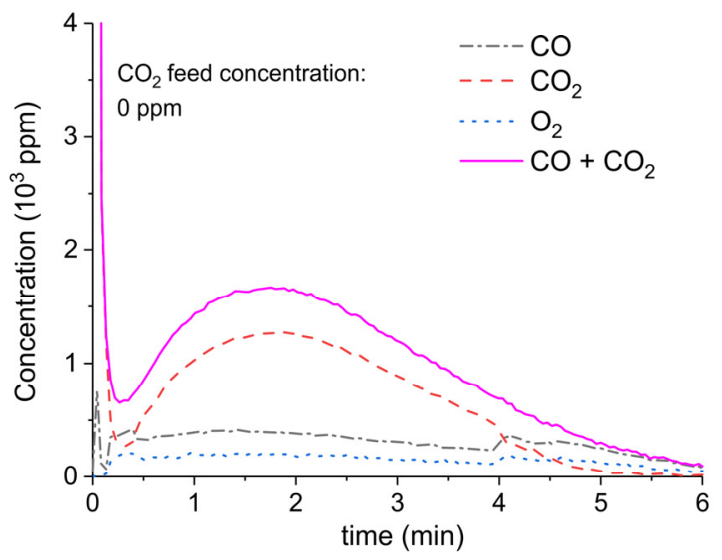

(e)

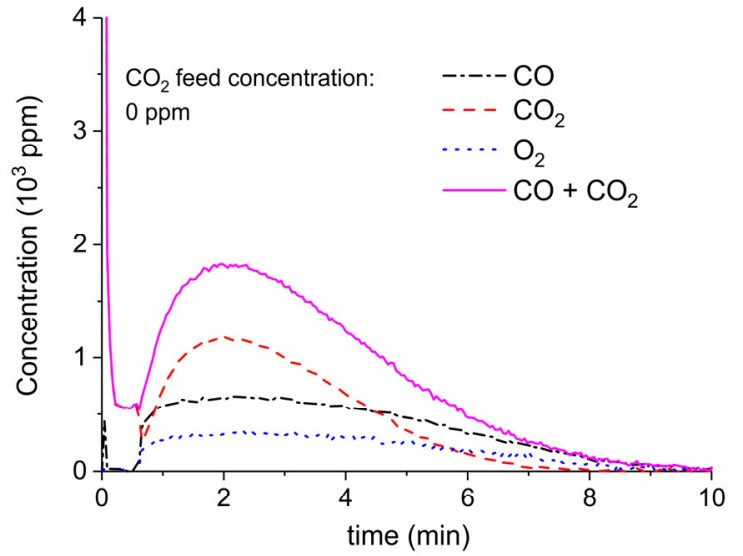

(b)

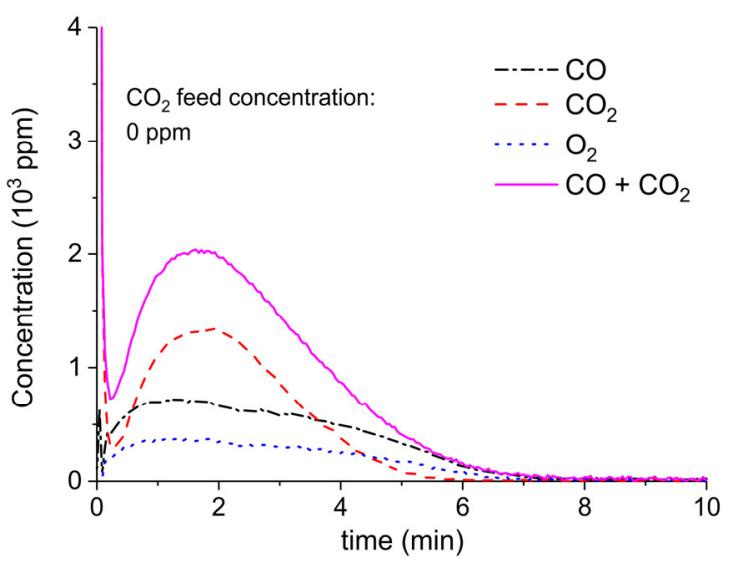

(d)

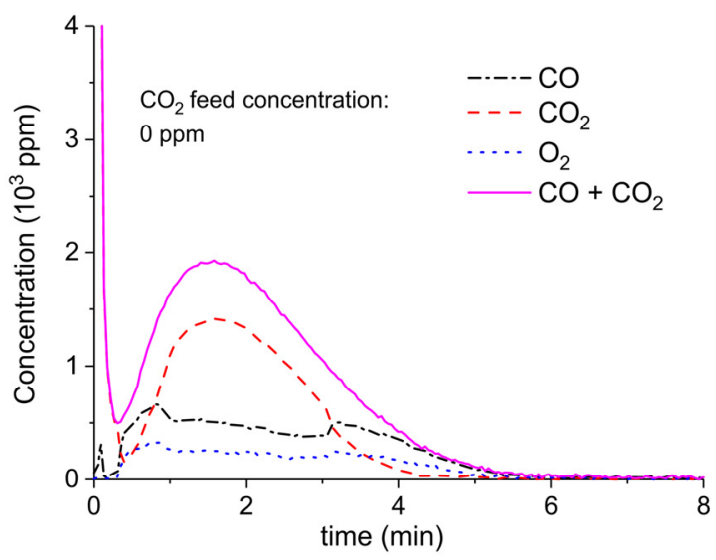

(f)

Figure A6. Cont. 


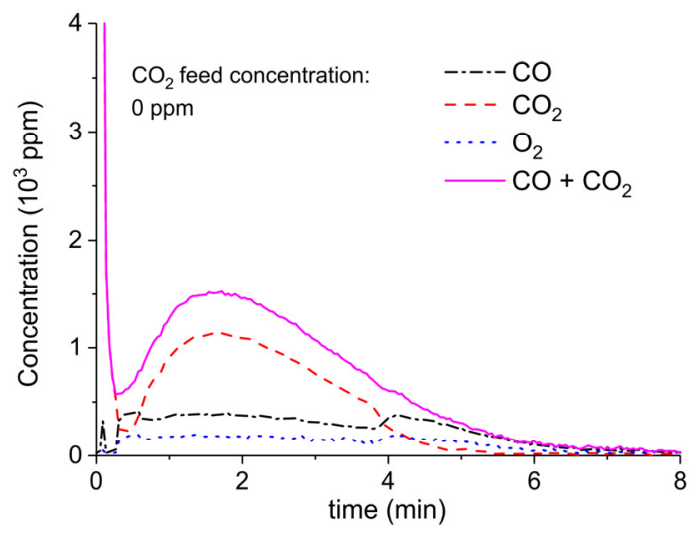

(g)

Figure A6. Concentration of the products of $\mathrm{CaCO}_{3}$ decomposition (sample $\mathrm{C}$ ) as function of time at $630^{\circ} \mathrm{C}$, flow rate of $90 \mathrm{~mL} / \mathrm{min}$. The fed $\mathrm{CO}_{2}$ concentration is $0 \mathrm{ppm}$ and the plasma power is $1.5 \mathrm{~W}(\mathbf{a})$, $2.1 \mathrm{~W}(\mathbf{b}), 1.7 \mathrm{~W}(\mathbf{c}), 2.2 \mathrm{~W}(\mathbf{d}), 1.5 \mathrm{~W}(\mathbf{e}), 2 \mathrm{~W}(\mathbf{f})$, and $1.1 \mathrm{~W}(\mathbf{g})$. The plasma is applied at the beginning of the reaction. The decomposition cycles are in order $\# 2, \# 3, \# 7, \# 8, \# 10, \# 11, \# 19$.

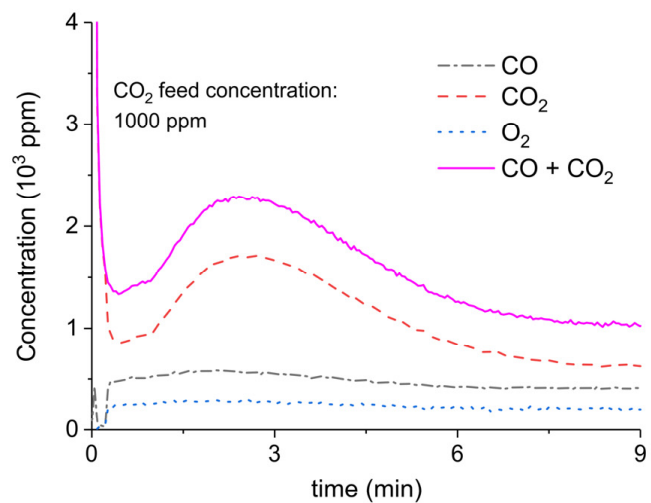

(a)

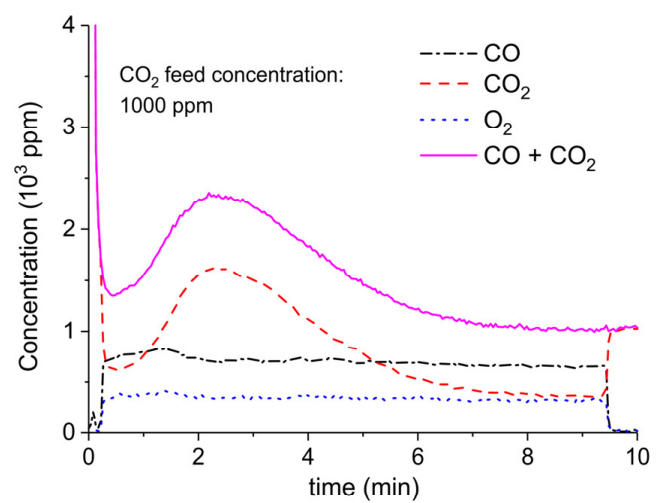

(b)

Figure A7. Concentration of the products of $\mathrm{CaCO}_{3}$ decomposition (sample $\mathrm{C}$ ) as function of time at $630{ }^{\circ} \mathrm{C}$, flow rate of $90 \mathrm{~mL} / \mathrm{min}$. The fed $\mathrm{CO}_{2}$ concentration is $1000 \mathrm{ppm}$ and the plasma power is $1.3 \mathrm{~W}$ (a) and $1.5 \mathrm{~W}(\mathbf{b})$. The plasma is applied at the beginning of the reaction. The decomposition cycles are in order \#20, \#21.

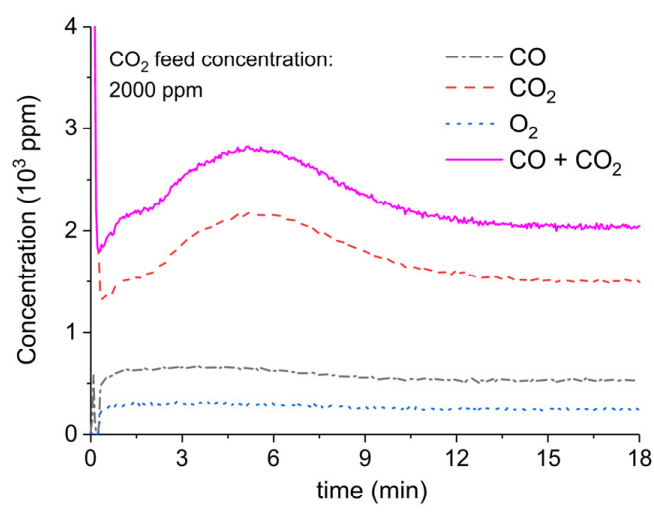

(a)

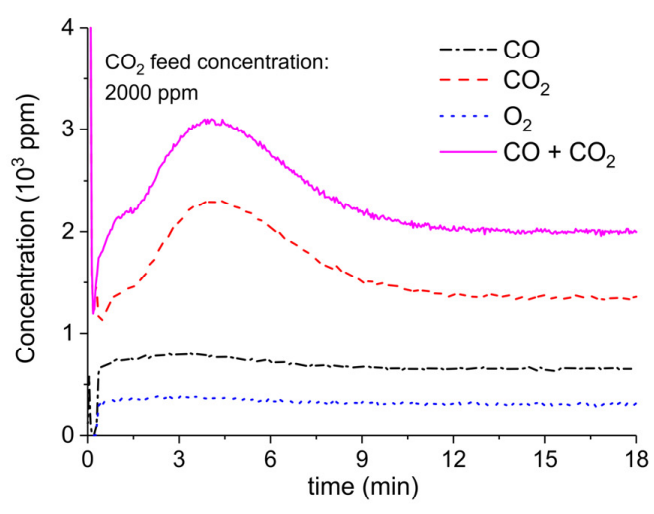

(b)

Figure A8. Concentration of the products of $\mathrm{CaCO}_{3}$ decomposition (sample $\mathrm{C}$ ) as function of time at $630{ }^{\circ} \mathrm{C}$, flow rate of $90 \mathrm{~mL} / \mathrm{min}$. The fed $\mathrm{CO}_{2}$ concentration is $2000 \mathrm{ppm}$ and the plasma power is $1.4 \mathrm{~W}$ (a) and $1.9 \mathrm{~W}(\mathbf{b})$. The plasma is applied at the beginning of the reaction. The decomposition cycles are in order \#13,\#14. 


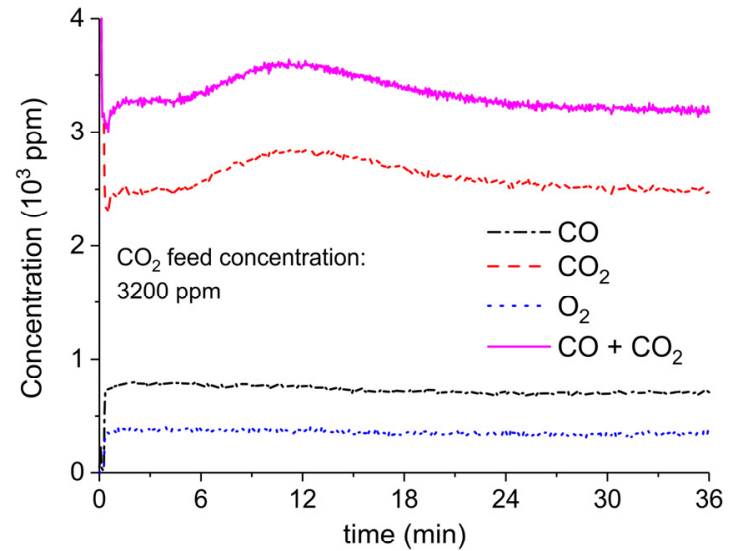

(a)

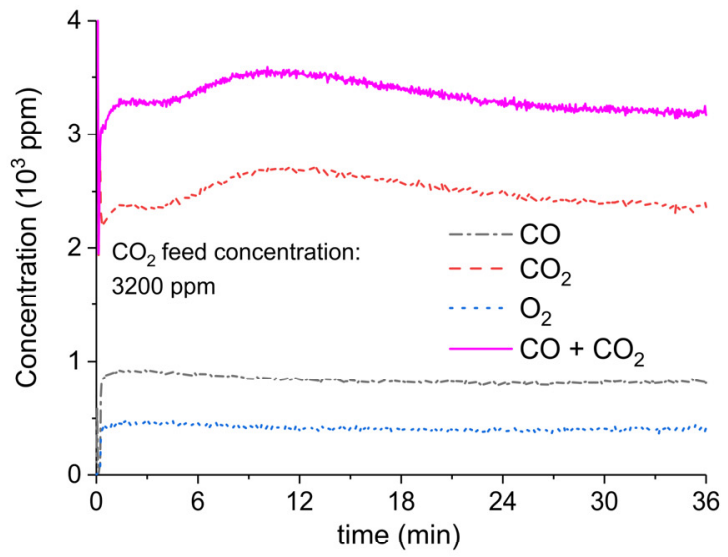

(b)

Figure A9. Concentration of the products of $\mathrm{CaCO}_{3}$ decomposition (sample $\mathrm{C}$ ) as function of time at $630{ }^{\circ} \mathrm{C}$, flow rate of $90 \mathrm{~mL} / \mathrm{min}$. The fed $\mathrm{CO}_{2}$ concentration is $3200 \mathrm{ppm}$ and the plasma power is $1.4 \mathrm{~W}$ (a) and $1.5 \mathrm{~W}(\mathbf{b})$. The plasma is applied at the beginning of the reaction. The decomposition cycles are in order \#16, \#17.

Appendix A.2. $\mathrm{CO}_{2}$ Dissociation with Only $\alpha-\mathrm{Al}_{2} \mathrm{O}_{3}$

Figure A10 shows the result of $\mathrm{CO}_{2}$ dissociation experiments on a sample consisting of $100 \mathrm{mg}$ $\alpha-\mathrm{Al}_{2} \mathrm{O}_{3}$ with particle size of $250-300 \mu \mathrm{m}$. The applied gas composition is respectively $1000 \mathrm{ppm}$ (Figure A10a), 2000 ppm (Figure A10b), and 3200 ppm (Figure A10c) in Argon. The CO concentrations at $1.5 \mathrm{~W}$ plasma power are obtained by interpolation and showed in Figure 11.

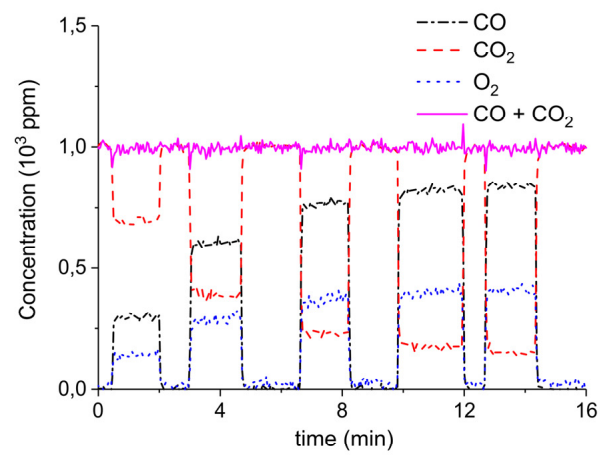

(a)

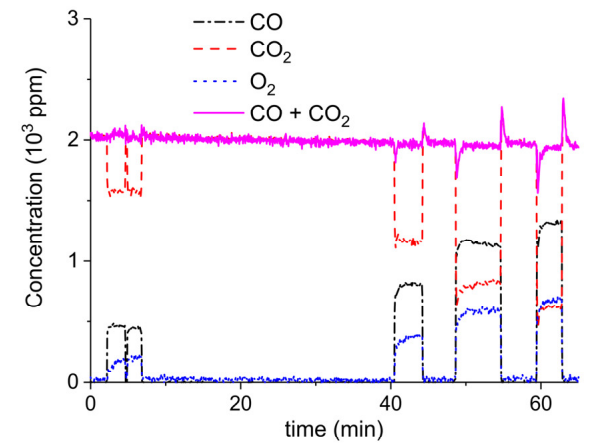

(b)

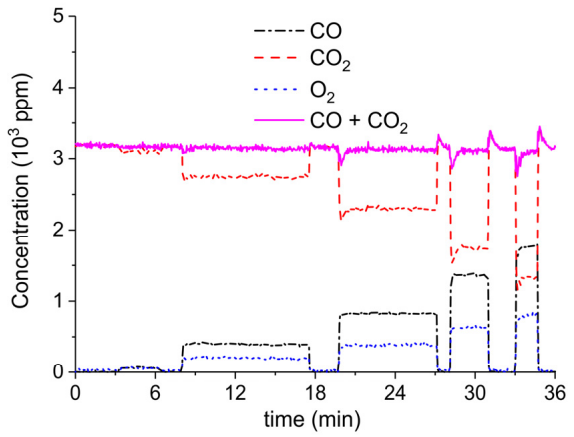

(c)

Figure A10. Concentration of the products of $\mathrm{CO}_{2}$ dissociation on $100 \mathrm{mg} \alpha-\mathrm{Al}_{2} \mathrm{O}_{3}$, particle size of 250-300 $\mu \mathrm{m}$, as function of time at $630{ }^{\circ} \mathrm{C}$, flow rate of $90 \mathrm{~mL} / \mathrm{min}$. The fed $\mathrm{CO}_{2}$ concentration is 1000ppm (a), 2000ppm (b), and 3200ppm (c); the plasma powers are 0.6, 1.6, 3.1, 4.8, and 7.2 W (a); 0.7, $1.8,4.1$, and $5.6 \mathrm{~W}(\mathrm{~b})$; and $0.5,1.5,3.1$, and $4.9 \mathrm{~W}$ (c). The plasma is applied for a few minutes and then turned off. 
Figure $\mathrm{A} 11$ shows the result of a $\mathrm{CaCO}_{3}$ decomposition experiment at $680{ }^{\circ} \mathrm{C}$ without plasma on sample $\mathrm{C}$. It is observed that the $\mathrm{CO}_{2}$ concentration at the steady state corresponds within the error margins to the sum of $\mathrm{CO}$ and $\mathrm{CO}_{2}$ concentrations during decomposition at $630^{\circ} \mathrm{C}$ with $3.2 \mathrm{~W}$ plasma power, shown in Figure A3a. The comparison supports the estimation of a $50{ }^{\circ} \mathrm{C}$ increase for $3.2 \mathrm{~W}$, as shown in Figure 11.

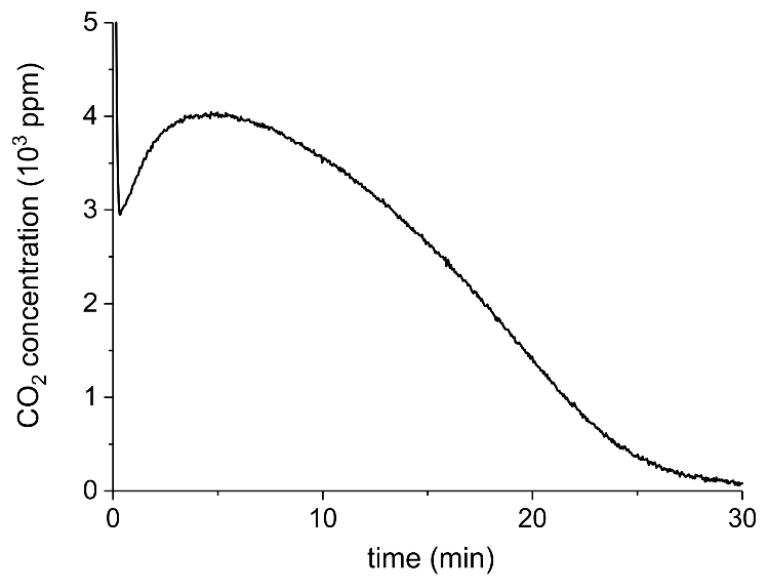

Figure A11. Concentration of $\mathrm{CO}_{2}$ during $\mathrm{CaCO} 3$ decomposition (sample $\mathrm{C}$ ) as function of time at $680^{\circ} \mathrm{C}$ and a flow rate of $30 \mathrm{~mL} / \mathrm{min}$.

\section{Appendix B.}

\section{Appendix B.1. Determination of Plasma Power}

The Lissajous plot measured during decomposition of sample $\mathrm{C}$ in Ar with $3200 \mathrm{ppm}$ extra $\mathrm{CO}_{2}$ and plasma power $1.5 \mathrm{~W}$, indicating plasma charge as function of voltage for one cycle, is shown in Figure A12. The hysteresis has a shape of parallelogram, indicating that a plasma is generated inside the reactor. The slopes of the two sides indicate respectively a cell capacity of $2.8 \mathrm{pF}$ with plasma off and an effective capacity of $8 \mathrm{pF}$ corresponding to the dielectric capacity and indicating that the plasma occupies the whole empty volume within the electrodes. The power of the plasma is calculated based on the area of the parallelogram:

$$
P=\frac{1}{T} \cdot \int_{0}^{T} V d Q
$$

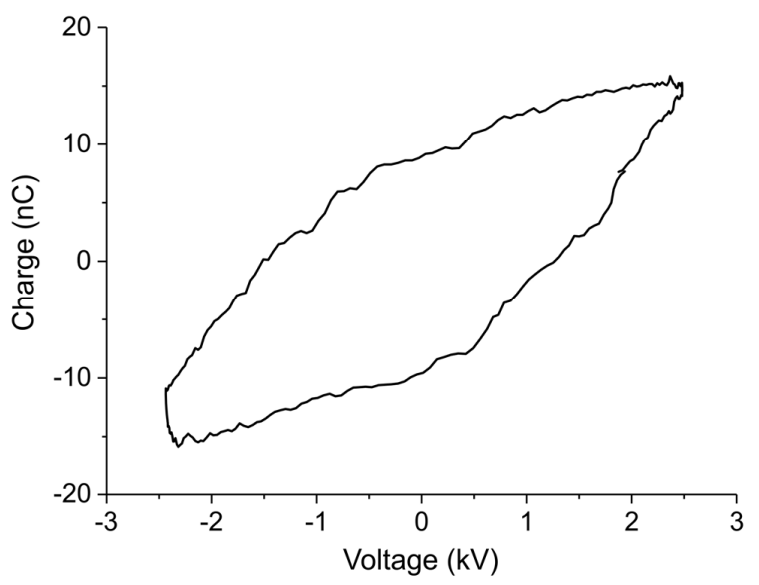

Figure A12. Lissajous plot of $1.5 \mathrm{~W}$ plasma applied on the $\mathrm{CaCO}_{3}$ and $\mathrm{Al}_{2} \mathrm{O}_{3}$ mixture with $3200 \mathrm{ppm}$ of $\mathrm{CO}_{2}$ in Ar. 


\section{Appendix B.2. Method}

The assumptions made in order to evaluate the argon plasma effect on calcium carbonate decomposition are the following:

- According to the Paschen's Law the electron filaments and active species cannot exist inside the pores of the carbonate particles, this is explained in the following paragraph.

- Temperature gradients between particles outer surface and inner core are minimized within much smaller times than the duration of the experiment, i.e., within $2 \mathrm{~min}$, according to the Fourier time calculated in the specific case.

Figure A13 shows the voltage needed to generate a plasma as function of the distance between the charges at an argon pressure of $1 \mathrm{~atm}$, where the parameters $A, B$, and $\gamma$ are determined experimentally [59]. The physical mechanism can be explained for the 2 branches of the curve:

- $d_{\text {gap }}>6 \mu \mathrm{m}$ : In order to generate a discharge (that is produced by an avalanche of ionizations of Argon atoms by high energy electrons), we need a minimum electric field that is able to accelerate electrons above the ionization energy of Ar atoms in the mean free path of electrons at that pressure $($ ca. $0.5 \mu \mathrm{m})$. Since the electric field is inversely proportional to $d_{\text {gap }}$ at constant voltage, $\mathrm{V}_{\mathrm{b}}$ increases linearly with $\mathrm{d}_{\text {gap }}$.

- $d_{g a p}<6 \mu m$ : the gap distance is comparable with the mean free path, so the probability of collisions that produce ionizations decreases. In order to have enough collisions to produce a discharge, the voltage has to be increased.

It follows that plasma cannot form in the pores of $\mathrm{CaCO}_{3}$ particles within the plasma zone, since their diameter is below $2 \mu \mathrm{m}$.

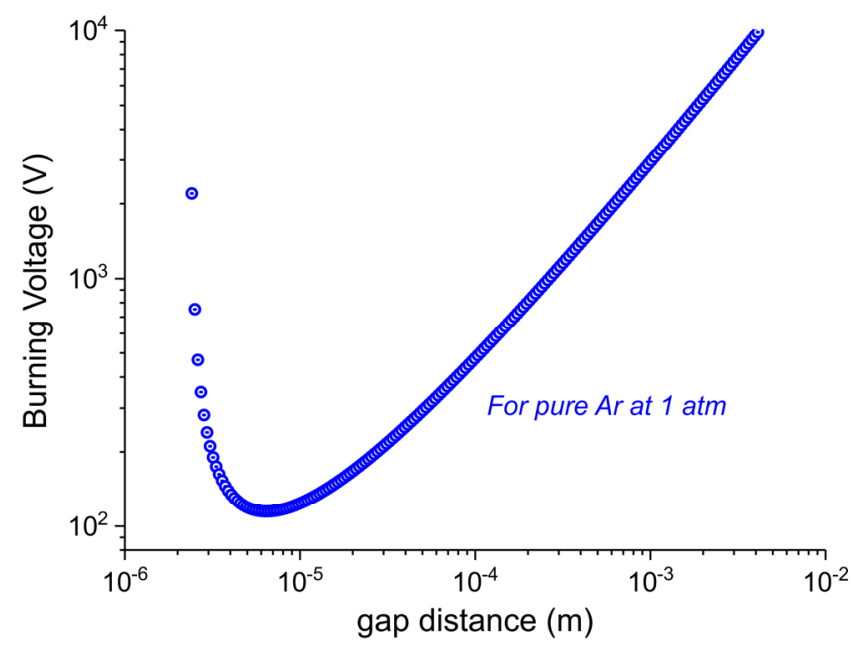

Figure A13. Burning voltage in function of the gap distance for argon at $1 \mathrm{~atm}$, as calculated by [59].

In order to discriminate whether the gas temperature increment or the active species drives the $\mathrm{CaCO}_{3}$ decomposition in presence of plasma, we compared the effect of plasma on the reaction rate on samples with different specific surface area and perform a similar comparison for samples with different particles size. By choosing different particles sizes or different specific surface areas, we can vary selectively the external surface, exposed to the active species and temperature increase, and the internal surface, exposed only to a temperature increase.

\section{Appendix B.3. $\mathrm{CO}_{2}$ and $\mathrm{CO}$ and Calibration}

Figure A14 shows the $\mathrm{CO}_{2}$ signal elaborated by MS (m/e = 44) for $\mathrm{CO}_{2}$ concentrations up to $5 \%$ in $\mathrm{Ar}$ and in the inset $\mathrm{CO}_{2}$ concentrations up to $1000 \mathrm{ppm}$ are expanded. In this range the signal is 
linear with the $\mathrm{CO}_{2}$ concentration, with a $\mathrm{R}^{2}$ coefficient of 0.9996 . The $\mathrm{CO}$ signal $(\mathrm{m} / \mathrm{e}=28)$ for the $\mathrm{CO}$ concentration of $5 \%$ in $\mathrm{Ar}$ is $1.15 \pm 0.05$ times larger than the $\mathrm{CO}_{2}$ signal $(\mathrm{m} / \mathrm{e}=44)$ at the same $\mathrm{CO}_{2}$ concentration.

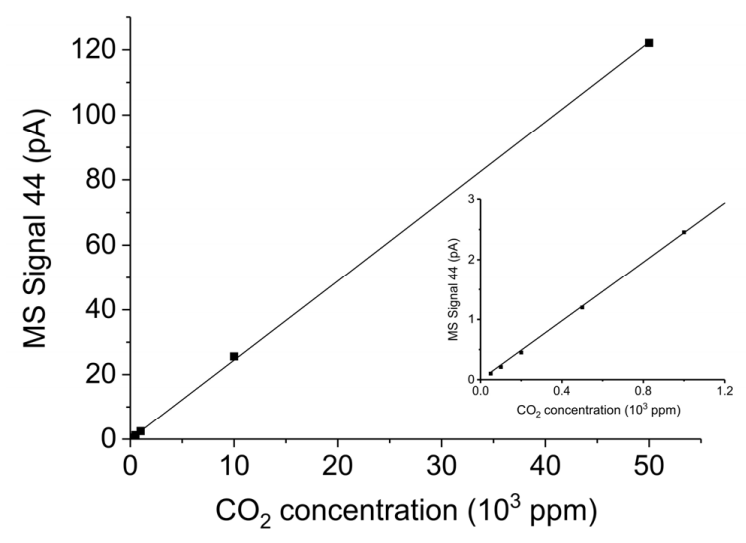

Figure A14. Mass spectrometer signal m/e = 44 for different $\mathrm{CO}_{2}$ concentrations in Ar from 0 to $5 \%$; inset: enhancement of the $\mathrm{CO}_{2}$ concentration range of 0 to $1000 \mathrm{ppm}$.

Appendix B.4. Sample Stability during Absorption-Desorption Cycles

Figure A15 shows the aging of the sample synthesized from calcium carbonate with the largest particles size, within 22 absorption-desorption cycles: the concentration of $\mathrm{CO}_{2}$ during the initial stage of decomposition does not show significant change during the 21 absorption-desorption cycles at $630^{\circ} \mathrm{C}$ in absence of extra $\mathrm{CO}_{2}$ and plasma, as expected for a sample already sintered at $900^{\circ} \mathrm{C}$ for $24 \mathrm{~h}$. The experiments in presence of extra $\mathrm{CO}_{2}$ and plasma were all performed from cycle 9 to cycle 22, where the sample shows the highest stability.

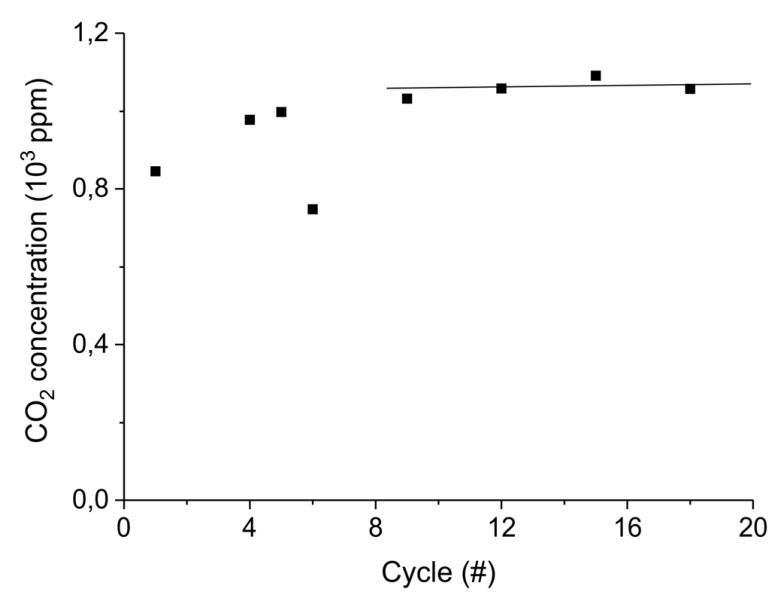

Figure A15. $\mathrm{CO}_{2}$ concentration at the first stage of decomposition of $10 \mathrm{mg} \mathrm{CaCO}_{3}$ for different cumulative number of cycles. The decompositions are performed at standard conditions, i.e., $630{ }^{\circ} \mathrm{C}$ without plasma in absence of $\mathrm{CO}_{2}$ in the gas mixture.

\section{Appendix B.5. Heat Transfer in the Packed Bed}

Plasma is considered as a uniform heat source at temperature $T_{\infty}$ around the particles which are assumed spherical and have an initial temperature $T_{0}$. We calculated the time needed to increase the temperature of the center of the particles of the $90 \%$ of the initial temperature difference $T_{\infty}-T_{0}$ as follows [60]

$$
t=\frac{\rho C_{p} V}{h A} \ln \left(\frac{T_{0}-T_{\infty}}{T-T_{\infty}}\right)
$$


The physical constants in the equation are the following: $\rho$ is the density of $\mathrm{CaCO}_{3}\left(2710 \mathrm{~kg} / \mathrm{m}^{3}\right)$; $C_{p}$ is the heat capacity of $\mathrm{CaCO}_{3}$ at $630{ }^{\circ} \mathrm{C}\left(1.26 \mathrm{~J} \mathrm{~g}^{-1} \mathrm{~K}^{-1}\right)$ [61]; $\mathrm{V}$ and $\mathrm{A}$ are the volume and section of the $\mathrm{CaCO}_{3}$ particles, respectively, and $\mathrm{h}$ is the convective heat transfer coefficient of a dry gas in a packed bed reactor, approximated to $15 \mathrm{~W} \mathrm{~m}^{-2} \mathrm{~K}^{-1}$ [60]. As a result, the times needed to heat up the particles are respectively 4,11 , and 24 seconds for the smallest (38-45 $\mu \mathrm{m})$, medium $(100-125 \mu \mathrm{m})$, and largest $(250-300 \mu \mathrm{m})$ particles, respectively. Equation (1) is an approximation for spherical particles without porosity, so we assume that more accurate calculation will give slightly longer times.

\section{References}

1. Neyts, E.C.; Ostrikov, K.; Sunkara, M.K.; Bogaerts, A. Plasma Catalysis: Synergistic Effects at the Nanoscale. Chem. Rev. 2015, 115, 13408-13446. [CrossRef] [PubMed]

2. Neyts, E.C.; Bogaerts, A. Understanding plasma catalysis through modelling and simulation-A review. J. Phys. D Appl. Phys. 2014, 47, 224010. [CrossRef]

3. Neyts, E.C.; Ostrikov, K.; Sunkara, M.K.; Bogaerts, A. Plasma-Surface Interactions in Plasma Catalysis. Plasma Chem. Plasma Process. 2014, 36, 13408-13446. [CrossRef]

4. Whitehead, J.C. Plasma-catalysis: The known knowns, the known unknowns and the unknown unknowns. J. Phys. D Appl. Phys. 2016, 49, 243001. [CrossRef]

5. Chen, H.L.; Lee, H.M.; Chen, S.H.; Chang, M.B.; Yu, S.J.; Li, S.N. Removal of volatile organic compounds by single-stage and two-stage plasma catalysis systems: A review of the performance enhancement mechanisms, current status, and suitable applications. Environ. Sci. Technol. 2009, 43, 2216-2227. [CrossRef] [PubMed]

6. Dobslaw, D.; Schulz, A.; Helbich, S.; Dobslaw, C.; Engesser, K.H. VOC removal and odor abatement by a low-cost plasma enhsnced biotrickling filter process. J. Environ. Chem. Eng. 2017, 5, 5501-5511. [CrossRef]

7. Kozàk, T.; Bogaerts, A. Splitting of $\mathrm{CO}_{2}$ by vibrational excitation in non-equilibrium plasmas: A reaction kinetics model. Plasma Sources Sci. Technol. 2014, 23, 045004. [CrossRef]

8. Ashford, B.; $\mathrm{Tu}, \mathrm{X}$. Non-thermal plasma technology for the conversion of $\mathrm{CO}_{2}$. Curr. Opin. Green Sustain. Chem. 2017, 3, 45-49. [CrossRef]

9. Michielsen, I.; Uytdenhouwen, Y.; Pype, J.; Michielsen, B.; Mertens, J.; Reniers, F.; Meynen, V.; Bogaerts, A. $\mathrm{CO}_{2}$ dissociation in a packed bed DBD reactor: First steps towards a better understanding of plasma catalysis. Chem. Eng. J. 2017, 326, 477-488. [CrossRef]

10. Grofulović, M.; Silva, T.; Klarenaar, B.L.; Morillo-Candas, A.S.; Guaitella, O.; Engeln, R.; Pintassilgo, C.D.; Guerra, V. Kinetic study of $\mathrm{CO}_{2}$ plasmas under non-equilibrium conditions. \{I\}. Relaxation of vibrational energy. Plasma Sources Sci. Technol. 2018, 27, 15019. [CrossRef]

11. Sobacchi, M.G.; Saveliev, A.V.; Fridman, A.A.; Kennedy, L.A.; Ahmed, S.; Krause, T. Experimental assessment of a combined plasma/catalytic system for hydrogen production via partial oxidation of hydrocarbon fuels. Int. J. Hydrogen Energy 2002, 27, 635-642. [CrossRef]

12. Tu, X.; Whitehead, J.C. Plasma-catalytic dry reforming of methane in an atmospheric dielectric barrier discharge: Understanding the synergistic effect at low temperature. Appl. Catal. B Environ. 2012, 125, 439-448. [CrossRef]

13. Chung, W.C.; Chang, M.B. Review of catalysis and plasma performance on dry reforming of $\mathrm{CH}_{4}$ and possible synergistic effects. Renew. Sustain. Energy Rev. 2016, 62, 13-31. [CrossRef]

14. Patil, B.S.; Wang, Q.; Hessel, V.; Lang, J. Plasma $\mathrm{N}_{2}$-fixation: 1900-2014. Catal. Today 2015, 256, 49-66. [CrossRef]

15. Fridman, A. Plasma Chemistry; Cambridge University Press: Cambridge, UK, 2008.

16. Tendero, C.; Tixier, C.; Tristant, P.; Desmaison, J.; Leprince, P. Atmospheric pressure plasmas: A review. Spectrochim. Acta Part B At. Spectrosc. 2006, 61, 2-30. [CrossRef]

17. Kim, H.H.; Teramoto, Y.; Negishi, N.; Ogata, A. A multidisciplinary approach to understand the interactions of nonthermal plasma and catalyst: A review. Catal. Today 2015, 256, 13-22. [CrossRef]

18. Aerts, R.; Somers, W.; Bogaerts, A. Carbon Dioxide Splitting in a Dielectric Barrier Discharge Plasma: A Combined Experimental and Computational Study. ChemSusChem 2015, 8, 702-716. [CrossRef]

19. Mei, D.; Zhu, X.; He, Y.L.; Yan, J.D.; Tu, X. Plasma-assisted conversion of $\mathrm{CO}_{2}$ in a dielectric barrier discharge reactor: Understanding the effect of packing materials. Plasma Sources Sci. Technol. 2015, 24, 015001. 
20. Nizio, M.; Albarazi, A.; Cavadias, S.; Amouroux, J.; Galvez, M.E.; da Costa, P. Hybrid plasma-catalytic methanation of $\mathrm{CO}_{2}$ at low temperature over ceria zirconia supported Ni catalysts. Int. J. Hydrogen Energy 2016, 41, 11584-11592. [CrossRef]

21. Bogaerts, A.; Kozák, T.; van Laer, K.; Snoeckx, R. Plasma-based conversion of $\mathrm{CO}_{2}$ : Current status and future challenges. Faraday Discuss. 2015, 183, 217-232. [CrossRef]

22. van Laer, K.; Bogaerts, A. Improving the Conversion and Energy Efficiency of Carbon Dioxide Splitting in a Zirconia-Packed Dielectric Barrier Discharge Reactor. Energy Technol. 2015, 3, 1038-1044. [CrossRef]

23. Brehmer, F.; Welzel, S.; van de Sanden, M.C.M.; Engeln, R. CO and byproduct formation during $\mathrm{CO}_{2}$ reduction in dielectric barrier discharges. J. Appl. Phys. 2014, 116, 123303. [CrossRef]

24. Uytdenhouwen, Y.; van Alphen, S.; Michielsen, I.; Meynen, V.; Cool, P.; Bogaerts, A. A packed-bed DBD micro plasma reactor for $\mathrm{CO}_{2}$ dissociation: Does size matter? Chem. Eng. J. 2018, 348, 557-568. [CrossRef]

25. Ramakers, M.; Michielsen, I.; Aerts, R.; Meynen, V.; Bogaerts, A. Effect of argon or helium on the $\mathrm{CO}_{2}$ conversion in a dielectric barrier discharge. Plasma Process. Polym. 2015, 12, 755-763. [CrossRef]

26. Zeng, Y.; Tu, X. Plasma-catalytic hydrogenation of $\mathrm{CO}_{2}$ for the cogeneration of $\mathrm{CO}$ and $\mathrm{CH}_{4}$ in a dielectric barrier discharge reactor: Effect of argon addition. J. Phys. D Appl. Phys. 2017, 50, 184004. [CrossRef]

27. Butterworth, T.; Elder, R.; Allen, R. Effects of particle size on $\mathrm{CO}_{2}$ reduction and discharge characteristics in a packed bed plasma reactor. Chem. Eng. J. 2016, 293, 55-67. [CrossRef]

28. Kameshima, S.; Tamura, K.; Ishibashi, Y.; Nozaki, T. Pulsed dry methane reforming in plasma-enhanced catalytic reaction. Catal. Today 2015, 256, 67-75. [CrossRef]

29. Kameshima, S.; Tamura, K.; Mizukami, R.; Yamazaki, T.; Nozaki, T. Parametric analysis of plasma-assisted pulsed dry methane reforming over $\mathrm{Ni} / \mathrm{Al}_{2} \mathrm{O}_{3}$ catalyst. Plasma Process. Polym. 2017, 14, 1600096. [CrossRef]

30. Ozkan, A.; Dufour, T.; Arnoult, G.; de Keyzer, P.; Bogaerts, A.; Reniers, F. $\mathrm{CO}_{2}-\mathrm{CH}_{4}$ conversion and syngas formation at atmospheric pressure using a multi-electrode dielectric barrier discharge. J. CO2 Util. 2015, 9, 78-81. [CrossRef]

31. Tu, X.; Gallon, H.J.; Twigg, M.V.; Gorry, P.A.; Whitehead, J.C. Dry reforming of methane over a Ni/ $\mathrm{Al}_{2} \mathrm{O}_{3}$ catalyst in a coaxial dielectric barrier discharge reactor. J. Phys. D Appl. Phys. 2011, 44, 274001. [CrossRef]

32. Gallon, H.J.; Tu, X.; Whitehead, J.C. Effects of reactor packing materials on $\mathrm{H}_{2}$ production by $\mathrm{CO}_{2}$ reforming of $\mathrm{CH}_{4}$ in a dielectric barrier discharge. Plasma Process. Polym. 2012, 9, 90-97. [CrossRef]

33. Zeng, Y.; Zhu, X.; Mei, D.; Ashford, B.; Tu, X. Plasma-catalytic dry reforming of methane over $\gamma-\mathrm{Al}_{2} \mathrm{O}_{3}$ supported metal catalysts. Catal. Today 2015, 256, 80-87. [CrossRef]

34. Zheng, X.; Tan, S.; Dong, L.; Li, S.; Chen, H. Silica-coated $\mathrm{LaNiO}_{3}$ nanoparticles for non-thermal plasma assisted dry reforming of methane: Experimental and kinetic studies. Chem. Eng. J. 2015, 265, 147-156. [CrossRef]

35. Aerts, R.; Martens, T.; Bogaerts, A. Influence of vibrational states on $\mathrm{CO}_{2}$ splitting by dielectric barrier discharges. J. Phys. Chem. C 2012, 116, 23257-23273. [CrossRef]

36. Bogaerts, A.; Wang, W.; Berthelot, A.; Guerra, V. Modeling plasma-based $\mathrm{CO}_{2}$ conversion: Crucial role of the dissociation cross section. Plasma Sources Sci. Technol. 2016, 25, 55016. [CrossRef]

37. Pietanza, L.D.; Colonna, G.; D'Ammando, G.; Capitelli, M. Time-dependent coupling of electron energy distribution function, vibrational kinetics of the asymmetric mode of $\mathrm{CO}_{2}$ and dissociation, ionization and electronic excitation kinetics under discharge and post-discharge conditions. Plasma Phys. Control. Fusion 2017, 59, 14035. [CrossRef]

38. Van Rooij, G.J.; van den Bekerom, D.C.; Den Harder, N.; Minea, T.; Berden, G.; Bongers, W.A.; Engeln, R.; Graswinckel, M.F.; Zoethout, E.; van de Sanden, M.C. Taming microwave plasma to beat thermodynamics in $\mathrm{CO}_{2}$ dissociation. Faraday Discuss. 2015, 183, 233-248. [CrossRef] [PubMed]

39. Bongers, W.; Bouwmeester, H.; Wolf, B.; Peeters, F.; Welzel, S.; van den Bekerom, D.; den Harder, N.; Goede, A.; Graswinckel, M.; Groen, P.W.; et al. Plasma-driven dissociation of $\mathrm{CO}_{2}$ for fuel synthesis. Plasma Process. Polym. 2017, 14, 1600126. [CrossRef]

40. Minea, T.; van den Bekerom, D.C.; Peeters, F.J.; Zoethout, E.; Graswinckel, M.F.; van de Sanden, M.C.; Cents, T.; Lefferts, L.; van Rooij, G.J. Non-oxidative methane coupling to $C_{2}$ hydrocarbons in a microwave plasma reactor. Plasma Process. Polym. 2018, 15, 1800087. [CrossRef]

41. Li, S.; Zheng, W.; Tang, Z.; Gu, F. Plasma heating and temperature difference between gas pellets in packed bed with dielectric barrier discharge under natural convection condition. Heat Transf. Eng. 2012, 33, 609-617. [CrossRef] 
42. Jidenko, N.; Bourgeois, E.; Borra, J.P. Temperature profiles in filamentary dielectric barrier discharges at atmospheric pressure. J. Phys. D Appl. Phys. 2010, 43, 295203. [CrossRef]

43. Patil, B.S.; Cherkasov, N.; Lang, J.; Ibhadon, A.O.; Hessel, V.; Wang, Q. Low temperature plasma-catalytic NOx synthesis in a packed DBD reactor: Effect of support materials and supported active metal oxides. Appl. Catal. B Environ. 2016, 194, 123-133. [CrossRef]

44. Nozaki, T.; Hiroyuki, T.; Okazaki, K. Hydrogen enrichment of low-calorific fuels using barrier discharge enhanced $\mathrm{Ni} / \gamma-\mathrm{Al}_{2} \mathrm{O}_{3}$ bed reactor: Thermal and nonthermal effect of nonequilibrium plasma. Energy Fuels 2006, 20, 339-345. [CrossRef]

45. Masoud, N.; Martus, K.; Figus, M.; Becker, K. Rotational and vibrational temperature measurements in a high-pressure cylindrical dielectric barrier discharge (C-DBD). Contrib. Plasma Phys. 2005, 45, 32-39. [CrossRef]

46. Rajasekaran, P.; Opländer, C.; Hoffmeister, D.; Bibinov, N.; Suschek, C.V.; Wandke, D.; Awakowicz, P. Characterization of dielectric barrier discharge (DBD) on mouse and histological evaluation of the plasma-treated tissue. Plasma Process. Polym. 2011, 8, 246-255. [CrossRef]

47. Du, Y.; Nayak, G.; Oinuma, G.; Ding, Y.; Peng, Z.; Bruggeman, P.J. Emission considering self-absorption of $\mathrm{OH}$ to simultaneously obtain the $\mathrm{OH}$ density and gas temperature: Validation, non-equilibrium effects and limitations. Plasma Sources Sci. Technol. 2017, 26, 095007. [CrossRef]

48. Florian, J.; Merbahi, N.; Wattieaux, G.; Plewa, J.M.; Yousfi, M. Comparative Studies of Double Dielectric Barrier Discharge and Microwave Argon Plasma Jets at Atmospheric Pressure for Biomedical Applications. IEEE Trans. Plasma Sci. 2015, 43, 3332-3338. [CrossRef]

49. Blamey, J.; Anthony, E.J.; Wang, J.; Fennell, P.S. The calcium looping cycle for large-scale $\mathrm{CO}_{2}$ capture. Prog. Energy Combust. Sci. 2010, 36, 260-279. [CrossRef]

50. McBride, B.J.; Zehe, M.J.; Gordon, S. NASA Glenn Coefficients for Calculating Thermodynamic Properties of Individual Species. In Technical Reports NASA; NASA: Washington, DC, USA, 2002; Volume 291, p. 211556.

51. Fennell, P.S.; Pacciani, R.; Dennis, J.S.; Davidson, J.F.; Hayhurst, A.N. The effects of repeated cycles of calcination and carbonation on a variety of different limestones, as measured in a hot fluidized bed of sand. Energy Fuels 2007, 21, 2072-2081. [CrossRef]

52. Lysikov, A.I.; Salanov, A.N.; Okunev, A.G. Change of $\mathrm{CO}_{2}$ carrying capacity of $\mathrm{CaO}$ in isothermal recarbonation-decomposition cycles. Ind. Eng. Chem. Res. 2007, 46, 4633-4638. [CrossRef]

53. Borgwardt, R.H. Sintering of nascent calcium oxide. Chem. Eng. Sci. 1989, 44, 53-60. [CrossRef]

54. Zhang, Y.R.; van Laer, K.; Neyts, E.C.; Bogaerts, A. Can plasma be formed in catalyst pores? A modeling investigation. Appl. Catal. B Environ. 2016, 185, 56-67. [CrossRef]

55. Hensel, K.; Katsura, S.; Mizuno, A. DC Microdischarges inside porous ceramics. IEEE Trans. Plasma Sci. 2005, 33, 574-575. [CrossRef]

56. Zhang, Q.Z.; Wang, W.Z.; Bogaerts, A. Importance of surface charging during plasma streamer propagation in catalyst pores. Plasma Sources Sci. Technol. 2018, 27, 065009. [CrossRef]

57. Giammaria, G.; Lefferts, L. Catalytic Effect of Water on Calcium Carbonate Decomposition. Appl. Catal. B, unpublished.

58. Peeters, F.J.J.; van de Sanden, M.C.M. The influence of partial surface discharging on the electrical characterization of DBDs. Plasma Sources Sci. Technol. 2015, 24, 15016. [CrossRef]

59. Ghassemi, M.; Mohseni, H.; Niayesh, K.; Shayegani, A.A. Dielectric Barrier Discharge (DBD) Dynamic Modeling for High Voltage Insulation. In Proceedings of the 2011 Electrical Insulation Conference (EIC), Annapolis, MD, USA, 5-8 June 2011.

60. Jess, A.; Wasserscheid, P. Chemical Technology; An Integrated Textbook; Wiley: Hoboken, NJ, USA, 2013.

61. Jacobs, G.K.; Kerrick, D.M.; Krupka, K.M. The High-Temperature Heat Capacity of Natural Calcite $\left(\mathrm{CaCO}_{3}\right)$. Phys. Chem. Miner. 1981, 7, 55-59. [CrossRef]

(C) 2019 by the authors. Licensee MDPI, Basel, Switzerland. This article is an open access article distributed under the terms and conditions of the Creative Commons Attribution (CC BY) license (http://creativecommons.org/licenses/by/4.0/). 